\title{
De-Novo Design of Cereblon (CRBN) Effectors Guided by Natural Hydrolysis Products of Thalidomide Derivatives
}

\author{
Christopher Heim, ${ }^{\dagger}$ Dimanthi Pliatsika, ${ }^{\ddagger}$ Farnoush Mousavizadeh, ${ }^{\ddagger}$ Kerstin Bär, ${ }^{\dagger}$ \\ Birte Hernandez Alvarez, ${ }^{\dagger}$ Athanassios Giannis, ${ }^{*}, \oplus$ and Marcus D. Hartmann ${ }^{*}, \dagger$
}

\begin{abstract}
${ }^{\dagger}$ Department of Protein Evolution, Max Planck Institute for Developmental Biology, Max-Planck-Ring 5, 72076 Tübingen, Germany ${ }^{\ddagger}$ Faculty for Chemistry und Mineralogy, Institute of Organic Chemistry, University of Leipzig, Johannisallee 29, 04103 Leipzig, Germany
\end{abstract}

\section{Supporting Information}

ABSTRACT: Targeted protein degradation via cereblon (CRBN), a substrate receptor of an E3 ubiquitin ligase complex, is an increasingly important strategy in various clinical settings, in which the substrate specificity of CRBN is altered via the binding of small-molecule effectors. To date, such effectors are derived from thalidomide and confer a broad substrate spectrum that is far from being fully characterized. Here, we employed a rational and modular approach to design novel and minimalistic CRBN effectors. In this approach, we took advantage of the binding modes of hydrolyzed metabolites of several thalidomide-derived effectors, which we elucidated via crystallography. These yielded key insights for the optimization of the minimal core binding moiety and its linkage to a chemical moiety that imparts substrate specificity. Based on this scaffold, we present a first active de-novo CRBN effector that is able to degrade the neo-substrate IKZF3 in the cell culture.

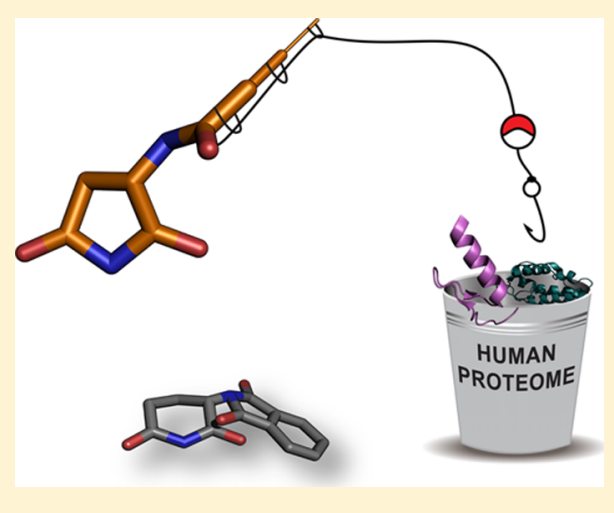

\section{INTRODUCTION}

Classical immunomodulatory drugs (IMiDs) like thalidomide and its second- and third-generation analogues lenalidomide, pomalidomide, avadomide (CC-122), and iberdomide (CC220) have constantly emerged to new therapeutic areas. Originally developed as a sedative ${ }^{1}$ and banned in 1961 for its teratogenic effects when used during pregnancy, ${ }^{2,3}$ thalidomide and a number of newly developed analogues are approved for the treatment of multiple myeloma (MM), ${ }^{4}$ erythema nodosum $^{5}$ and myelodysplastic syndrome (MDS). ${ }^{6,7}$ Because of their pleiotropic and especially anti-angiogenic properties, IMiDs have further been reported effective in many off-label indications as for Hodgkin's lymphoma, ${ }^{8-10}$ light chainassociated (AL) amyloidosis, ${ }^{11}$ and acute myeloid leukemia (AML). ${ }^{12,13}$

Currently, IMiDs share a common glutarimide moiety (Figure 1), which is connected to a second moiety that is typically derived from phthaloyl. Via the glutarimide moiety, they are able to bind to a tri-tryptophan pocket within the thalidomide-binding domain ${ }^{14-17}$ of cereblon (CRBN). CRBN is the substrate receptor of the Cullin RING E3 ubiquitin ligase CUL4-RBX1-DDB1-CRBN (CRL4 $\left.{ }^{\mathrm{CRBN}}\right)^{17}$ and responsible for the recognition of endogenous substrates such as glutamine synthetase, ${ }^{18}$ MEIS2, ${ }^{17}$ and amyloid precursor protein (APP). ${ }^{19}$ In the presence of IMiDs, however, its substrate specificity is changed. The solvent-exposed second moiety, the protruding moiety that is unique to each $\mathrm{IMiD}$, recruits novel substrates to the CRBN surface for ubiquitination. The degradation of these neo-substrates accounts for most of the efficacy of IMiDs in MM

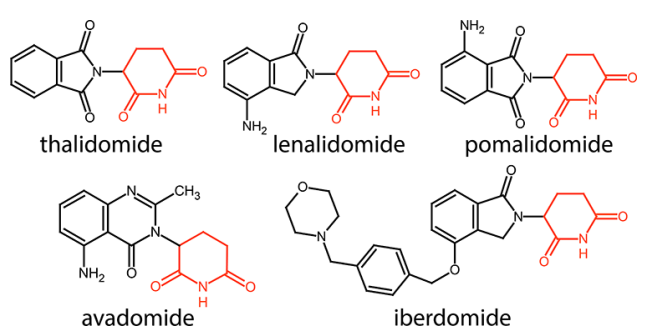

Figure 1. Chemical structures of thalidomide, lenalidomide, pomalidomide, avadomide, and iberdomide with their glutarimide moiety shown in red.

(IKZF1 and IKZF3), ${ }^{20} 5$ q-deletion-associated MDS (CK1 $\left.\alpha\right),{ }^{21}$ and AML (GSPT1). ${ }^{22}$ Recently, it has also been shown that the degradation of the neo-substrate SALL4 is linked to developmental malformations caused by thalidomide. ${ }^{23,24}$

Crystal structures of the neo-substrate complexes CRBN. lenalidomide $\mathrm{CK} 1 \alpha, \mathrm{CRBN} \cdot$ pomalidomide-IKZF1, and CRBN. pomalidomide ZNF692 provided first insights into the binding mode of neo-substrates. ${ }^{25,26}$ Many of the identified neosubstrates possess no obvious sequence homology, but they all exhibit a structurally analogous $\beta$-hairpin, which binds to the surface around the IMiD-binding site, involving interactions with both surface residues and the IMiD itself. A potential prerequisite for the recruitment is the presence of a glycine at the

Received: March 15, 2019

Published: June 28, 2019 
tip of this $\beta$-hairpin; this glycine was found to be conserved for many neo-substrates, like CK $1 \alpha^{25}$ and GSPT 1,22 and appears in the common C-X(2)-C-G motif ${ }^{24}$ in many transcription factors belonging to the $\mathrm{C}_{2} \mathrm{H}_{2}$ zinc finger class, including IKZF3, ${ }^{25}$ IKZF1, ${ }^{25}$ ZFP91, $^{24}$ and SALL4. ${ }^{24}$ While IMiDs seem to generally recruit several members of the $\mathrm{C}_{2} \mathrm{H}_{2}$ zinc finger family, only lenalidomide was proven to recruit $\mathrm{CK} 1 \alpha$, indicating that the protruding moiety imparts substrate specificity.

The CRBN-binding ability of IMiDs has further been exploited for targeted protein degradation in an approach called proteolysis targeting chimera (PROTAC), coined in 2001 by Craig Crews and co-workers. ${ }^{27,28}$ PROTACs are bifunctional small molecules with a binding moiety for a target protein linked to a binding moiety for an E3 ubiquitin ligase, thus inducing ubiquitination and proteasomal degradation of the target protein. Recent examples of successful PROTACs target the estrogen $^{29}$ and the androgen receptor ${ }^{30}$ via a von-Hippel-Lindau (VHL) E3 ligase ligand but also BET bromodomains via linkage to thalidomide as a CRBN ligand. ${ }^{31}$ Notably, also PROTACs with a VHL ligand on one and thalidomide as the CRBN ligand on the other end have been tested, leading to unidirectional degradation of CRBN. ${ }^{32}$ In general, also the PROTAC approach has high potential to target the undruggable; a particularly illustrative example for this potential is exemplified by the recent discovery of PROTACs targeting the tau protein. ${ }^{33-35}$

To date, essentially all CRBN effectors-IMiDs and CRBNbased PROTACs-are derived from thalidomide and its derivatives. However, the chemical space of CRBN ligands ranges far beyond thalidomide: in first systematic characterization, we have previously revealed that a large variety of lactams and cyclic imides are potent binders, including several marketed drugs. ${ }^{36}$ Specifically, we have shown succinimide to exhibit higher affinity than glutarimide, using the single-domain bacterial CRBN homologue from Magnetospirillum gryphiswaldense (MsCI4) in a FRET assay. ${ }^{14}$ In this study, we set out to further explore and exploit the chemical space of CRBN binding by designing effectors based on succinimide and glutarimide, which we characterize with regard to their affinity, their structural binding mode, and their ability to induce proteasomal degradation of neo-substrates. Guided by hydrolyzed metabolites of thalidomide and of three of our designs, we present novel minimalistic motifs that are able to recruit and degrade neosubstrates and may serve as E3-recruiting ligands for future PROTACs.

\section{RESULTS AND DISCUSSION}

Biophysical and Structural Characterization of IMiD Analogues and Their Hydrolysis Products. As a starting point for new effectors, we chose the classical IMiD scaffold. Based on the finding that succinimide is able to bind to CRBN with a higher affinity than glutarimide ( $K_{\mathrm{i}}$ values of $4.3 \mu \mathrm{M}$ vs 28 $\mu \mathrm{M}$ for MsCI $4^{36}$ ), we designed a first panel of derivatives based on glutarimide and succinimide, in which we probed the effect of different substitutions in the phthaloyl moiety (Figure 2). The respective compounds $\mathbf{2} \mathbf{a}-\mathbf{5 b}$ were prepared by the synthetic route shown in Scheme 1 . The imides $\mathbf{3 a}$ and $\mathbf{3 b}$ were synthesized from the commercially available $N_{\alpha^{-}}$(tert-butoxycarbonyl)-L-asparagine (1a) and $N_{\alpha^{-}}$(tert-butoxycarbonyl)-Lglutamine (1b), respectively, via an imide formation using $\mathrm{N}, \mathrm{N}$ carbodiimidazole (CDI) and 4-dimethylaminopyridine (4DMAP) in tetrahydrofuran (THF) as well as a deprotection reaction in the presence of trifluoracetic acid (TFA). Compounds $\mathbf{4 a - 4 d}$ were obtained through coupling between
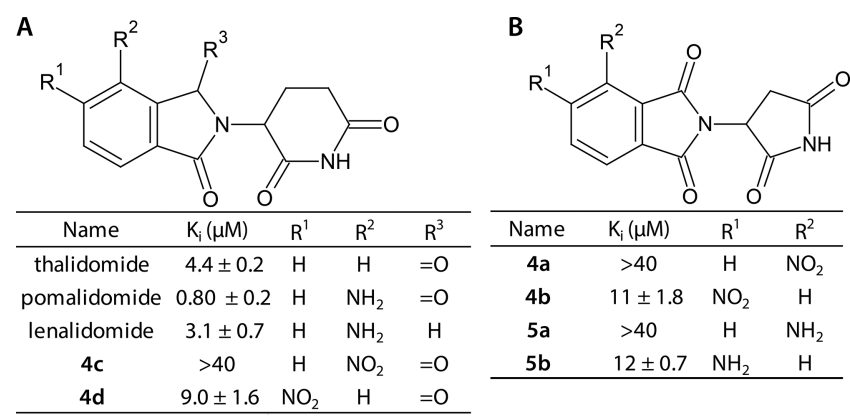

Figure 2. The first panel of chemical structures, five- and six-ring based thalidomide analogues and their affinity to MsCI4 determined as $K_{\mathrm{i}}$ values in the FRET assay.

the imides $\mathbf{3 a}$ or $\mathbf{3 b}$ and the commercially available 3nitrophthalic anhydride or 4-nitrophthalic anhydride. Catalytic hydrogenation of the molecules $4 \mathbf{a}$ and $\mathbf{4 b}$ using 10 wt \% Pd/C in EtOAc produced the derivatives $\mathbf{5 a}$ and $\mathbf{5} \mathbf{b}$.

The binding affinities of these compounds for MsCI4 were assessed in the FRET assay, starting with the glutarimide-based compounds $4 \mathrm{c}$ and $4 \mathrm{~d}$ in comparison to the commercial thalidomide derivatives, lenalidomide and pomalidomide. Lenalidomide $\left(K_{\mathrm{i}}=3.1 \mu \mathrm{M}\right)$ and pomalidomide $\left(K_{\mathrm{i}}=0.8\right.$ $\mu \mathrm{M})$, both carrying an additional amino group in the $\mathrm{R}^{2}$ position, show improved affinity to $\mathrm{MsCI} 4$ as compared to thalidomide $\left(K_{\mathrm{i}}=4.4 \mu \mathrm{M}\right)$. When we exchanged this amino group for a nitro group (4c), we saw a significant drop in affinity into a range in which a precise value could not be obtained $\left(K_{\mathrm{i}}>40 \mu \mathrm{M}\right){ }^{36}$ moving this nitro group to the $\mathrm{R}^{1}$ position (4d) had less impact on the affinity $\left(K_{\mathrm{i}}=8.9 \mu \mathrm{M}\right.$, Figure $\left.2 \mathrm{~A}\right)$. Similar effects were observed in a recent study that was published during the preparation of this manuscript. ${ }^{37}$ As both compounds, $4 \mathrm{c}$ and 4d, retained affinity to $\mathrm{MsCI} 4$, their overall binding mode is supposedly conserved and comparable to thalidomide, which is consistent with previous studies, showing that small modifications on the protruding moiety have little influence on the overall affinity to CRBN. ${ }^{17,37}$ The binding modes of lenalidomide and pomalidomide have previously been reported to be virtually identical to thalidomide. ${ }^{14,17}$

For the succinimide-based compounds $\mathbf{4 a}, \mathbf{4 b}, \mathbf{5} \mathbf{a}$, and $\mathbf{5 b}$, we obtained a similar picture as for the glutarimide-based compounds. Although they showed overall weaker binding in the FRET assay (Figure $2 \mathrm{~B}$ ), substitutions in the $\mathrm{R}^{2}$ position are less favorable for the affinity as substitutions in $\mathrm{R}^{1}$. For $\mathbf{4 a}$ and $\mathbf{5 a}$, which have a nitro or an amino group in $\mathrm{R}^{2}$, respectively, we obtained $K_{\mathrm{i}}$ values of $>40 \mu \mathrm{M}$. For $\mathbf{4 b}$ and $\mathbf{5 b}$, which have the respective groups in the $\mathrm{R}^{1}$ position, the obtained $K_{\mathrm{i}}$ values are 11 and $12 \mu \mathrm{M}$, respectively.

In a next step, we determined the molecular-binding determinants of the succinimide-based compounds via X-ray crystallography. To this end, crystals of the MsCI4-thalidomide complex were reproduced $^{36}$ and subsequently used for soaking experiments, in which the thalidomide molecules bound to $\mathrm{MsCI} 4$ may be displaced by the compound of interest. There are three chains, that is, three MsCI4-thalidomide complexes, in the asymmetric unit (ASU) of these crystals, in which the bound thalidomide molecules can potentially be displaced. However, as the three chains form different crystal contacts and differ slightly in their conformation, it is possible that thalidomide is only replaced in one or two chains of the ASU, depending on the particular compound. ${ }^{36}$ These experiments yielded crystal structures for the four compounds tested, $\mathbf{4 a}, \mathbf{4 b}, \mathbf{5} \mathbf{a}$, and $\mathbf{5 b}$, 
Scheme $1^{a}$
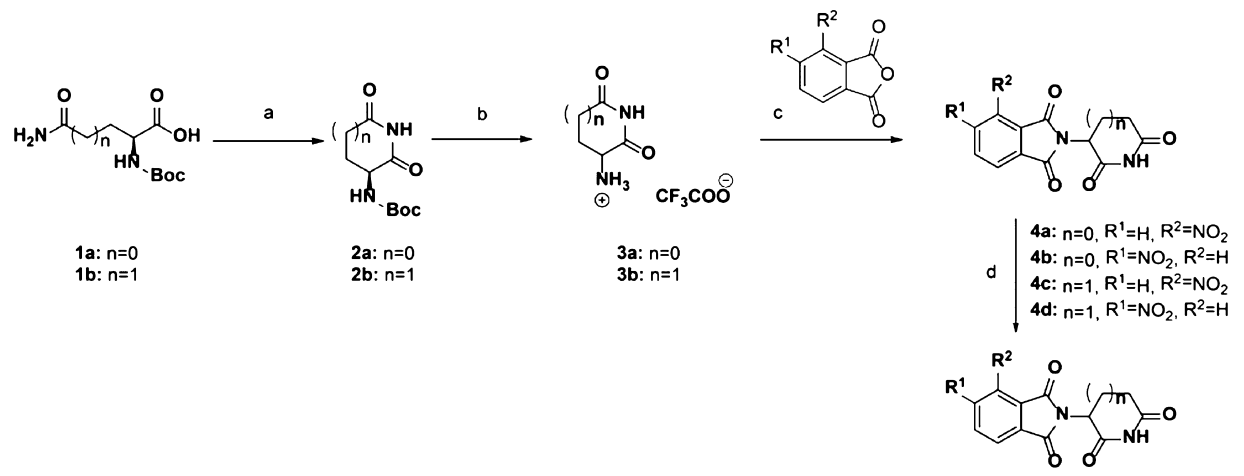

5a: $n=0, R^{1}=H, R^{2}=\mathrm{NH}_{2}$

5b: $n=0, R^{1}=\mathrm{NH}_{2}, \mathrm{R}^{2}=\mathrm{H}$

${ }^{a}$ Reagents and conditions: (a) CDI, 4-DMAP, THF, reflux, 17-48 h; (b) TFA, RT, 30 min; (c) CDI, 4-DMAP, THF, reflux, 5-20 h; and (d) 10 wt \% Pd/C, EtOAc, RT, 20 h.

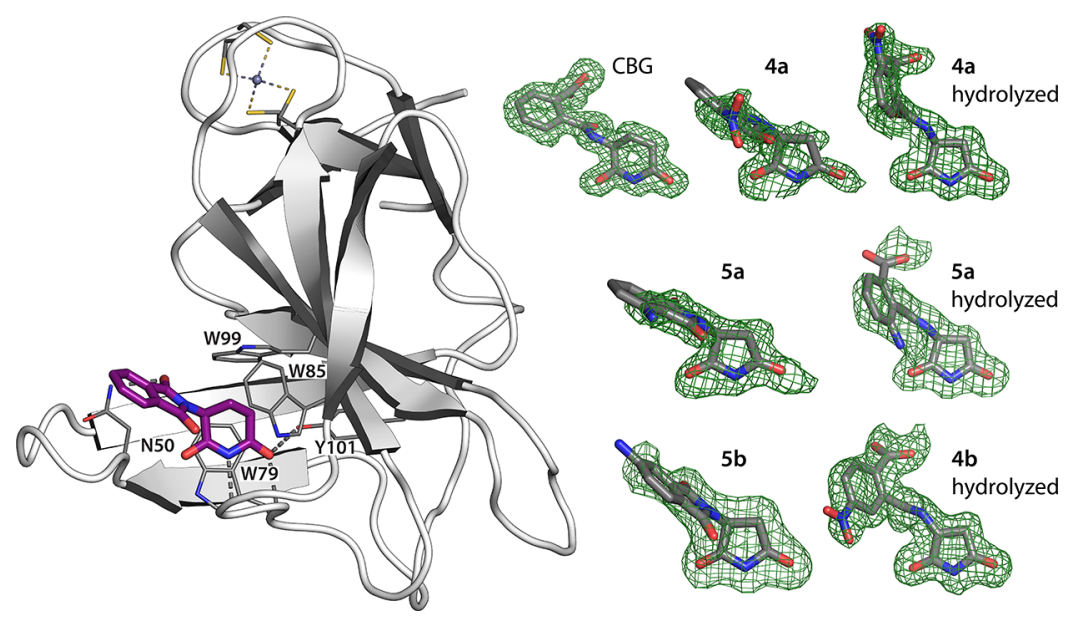

Figure 3. Overview of the thalidomide-binding mode and electron densities of thalidomide analogues and their hydrolysis products bound to MsCI4. Left: Cartoon representation of thalidomide-bound MsCI4 with key residues of the binding pocket shown as sticks. Right: $\mathrm{F}_{\mathrm{O}}-\mathrm{F}_{\mathrm{C}}$ maps of CBG (PDB 6R0Q), $4 a$ and hydrolyzed 4a (PDB 6R0S), hydrolyzed 4b (PDB 6R0V), 5a, and hydrolyzed 5a (PDB 6R0U) and 5b (PDB 6R11) in the MsCI4binding pocket, contoured at $2 \sigma$.

all showing the classical IMiD binding mode with the basal main-chain interactions of the succinimide amino group with F77 and the carbonyl group with W79 of MsCI4. Also, the orientation of the protruding moieties of $\mathbf{4 a}, \mathbf{5 a}$, and $\mathbf{5 b}$ is very similar to that of thalidomide, despite the different ring size of glutarimide and succinimide. As a result, the hydrogen bond that is typically observed between the conserved N50 and a carbonyl group of the phthaloyl moieties for the classical glutarimidebased compounds is also found for $\mathbf{5 b}$.

However, the crystal structures also held surprises. They did not only reveal the binding modes of the pure compounds but also that of hydrolysis products of $\mathbf{4 a}, \mathbf{4} \mathbf{b}$, and $\mathbf{5 a}$ with unambiguous electron density; only $\mathbf{5 b}$ was exclusively observed in the nonhydrolyzed form (Figures 3 and 4). For $\mathbf{4 a}$ and $\mathbf{5 a}$, hydrolyzed metabolites were only observed in one chain of the ASU, with the second chain occupied with a nonhydrolyzed version and the third chain with thalidomide. For $\mathbf{4 b}$, which showed the highest affinity with a $K_{\mathrm{i}}$ of $11 \mu \mathrm{M}$, all three binding pockets in the ASU were occupied by a hydrolyzed metabolite, so the binding mode of nonhydrolyzed $\mathbf{4 b}$ could not be studied. In all cases, for the hydrolysis products of $\mathbf{4 a}, \mathbf{4 b}$, and $\mathbf{5 a}$, ring opening of the phthaloyl group had led to the formation of a secondary amide and a carboxyl group, which are clearly resolved in $\mathrm{F}_{\mathrm{O}}-\mathrm{F}_{\mathrm{C}}$ omit maps (Figure 3). Both of these form important interactions with the binding pocket: first, the secondary amide rescues the hydrogen bond to the conserved N50, which is typically formed by a carbonyl of the phthaloyl moiety. Second, the additional carboxyl group replaces a conserved water molecule previously coordinated by W99 and engages in direct hydrogen bonding with the W99 side chain. In contrary, the primary amino group of hydrolyzed 5a and the solvent-exposed nitro groups of hydrolyzed $\mathbf{4 a}$ and $\mathbf{4 b}$ do not show additional interactions.

Binding Mode of CBG, a Major Hydrolysis Product of Thalidomide. Unintentionally, in addition to the hydrolysis products of $\mathbf{4 a}, \mathbf{4 b}$, and $\mathbf{5 a}$, we were able to characterize the binding mode of a major hydrolyzed thalidomide metabolite. It is known that IMiDs can rapidly racemize in bodily fluids and water $^{38}$ and spontaneously hydrolyze under physiological conditions. ${ }^{39-41}$ For thalidomide, being eliminated mainly by spontaneous hydrolysis in blood and tissues, a half-life of about $5.5-7.3 \mathrm{~h}$ at the physiological $\mathrm{pH}$ of 7.4 was reported. ${ }^{42}$ Among several proposed hydrolysis products, the two main urinary metabolites are 2-phthalimidoglutaramic acid $(\sim 50 \%)$ and $\alpha$ (2-carboxybenzamido)glutarimide (CBG) ( 30\%). ${ }^{43}$ Of these, $\mathrm{CBG}$ has an unmodified glutarimide moiety and is also one of 

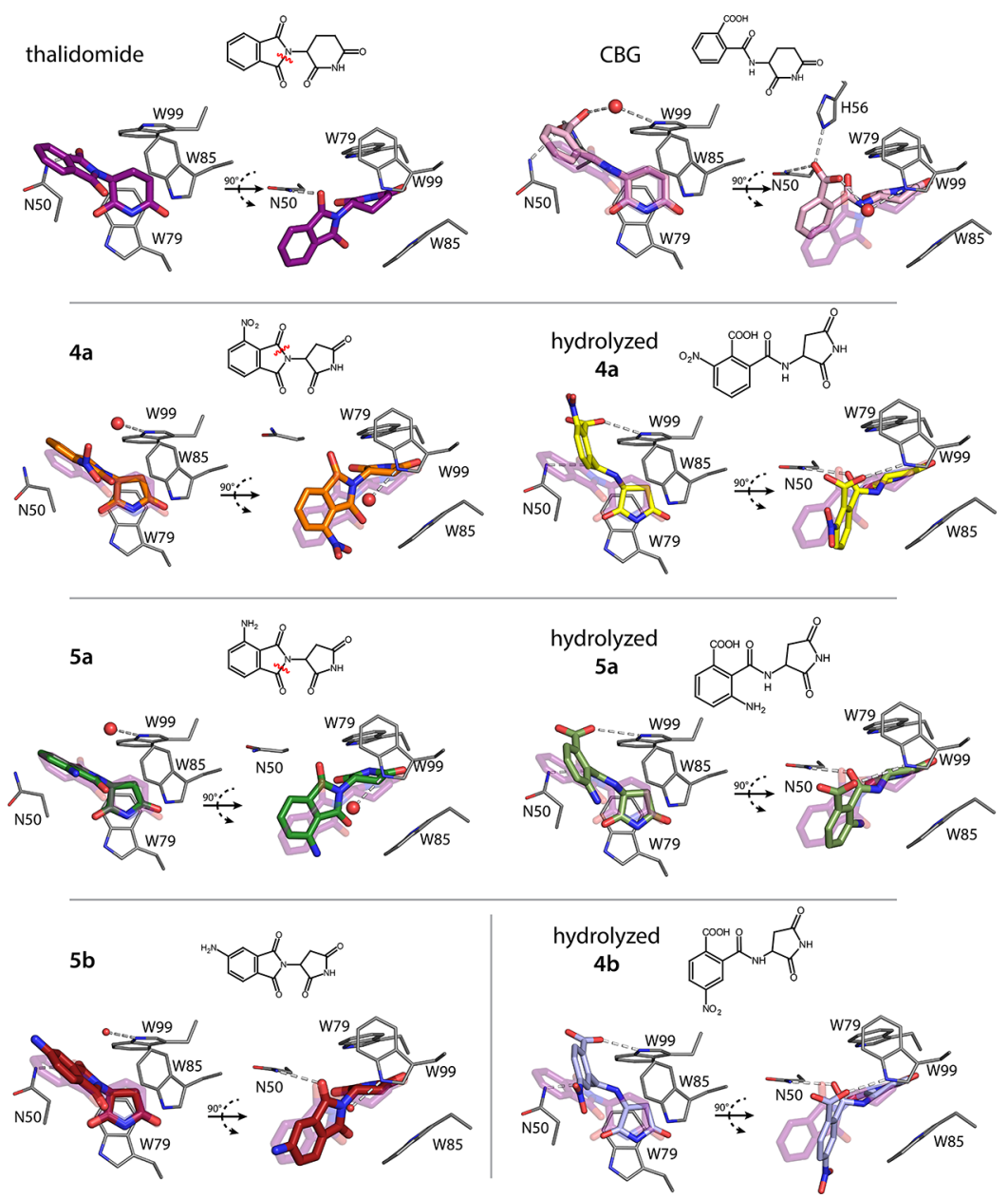

Figure 4. Binding mode of the initial compounds and their hydrolysis products inside the binding pocket. Thalidomide, 4a, and 5a are shown with their respective hydrolysis products. Ring opening of the phtaloyl moiety that leads to the observed hydrolysis product is indicated in red in the chemical drawings. $\mathbf{5 b}$ was exclusively found in the nonhydrolyzed form, whereas $\mathbf{4 b}$ was exclusively found as a hydrolysis product. PDB codes are 4V2Y (thalidomide), 6R0Q (CBG), 6R0S (4a), 6R0U (5a), 6R11 (5b), and 6R0V (4b).

\section{Scheme $2^{a}$}

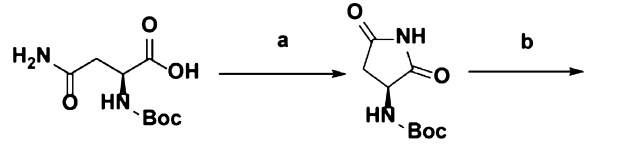

1a

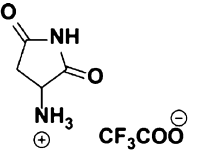

$3 a$

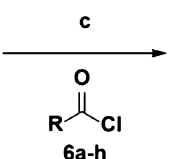

6a-h

2a

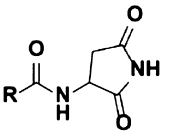

7a-h

$\begin{array}{ll}\text { 6a: } \mathrm{R}=\mathrm{C}_{4} \mathrm{H}_{7} & \text { 7a: } \mathrm{R}=\mathrm{C}_{4} \mathrm{H}_{7} \\ \text { 6b: } \mathrm{R}=\mathrm{C}_{7} \mathrm{H}_{7} & \text { 7b: } \mathrm{R}=\mathrm{C}_{7} \mathrm{H}_{7} \\ \text { 6c: } \mathrm{R}=\mathrm{C}_{6} \mathrm{H}_{2} \mathrm{Cl}_{3} & \text { 7c: } \mathrm{R}=\mathrm{C}_{6} \mathrm{H}_{2} \mathrm{Cl}_{3} \\ \text { 6d: } \mathrm{R}=\mathrm{C}_{7} \mathrm{H}_{7} \mathrm{O} & \text { 7d: } \mathrm{R}=\mathrm{C}_{7} \mathrm{H}_{7} \mathrm{O} \\ \text { 6e: } \mathrm{R}=\mathrm{C}_{6} \mathrm{H}_{3} \mathrm{~N}_{2} \mathrm{O}_{4} & \text { 7e: } \mathrm{R}=\mathrm{C}_{6} \mathrm{H}_{3} \mathrm{~N}_{2} \mathrm{O}_{4} \\ \text { 6f: } \mathrm{R}=\mathrm{C}_{8} \mathrm{H}_{7} & \text { 7f: } \mathrm{R}=\mathrm{C}_{8} \mathrm{H}_{7} \\ \text { 6g: } \mathrm{R}=\mathrm{C}_{8} \mathrm{H}_{4} \mathrm{ClS} & \text { 7g: } \mathrm{R}=\mathrm{C}_{8} \mathrm{H}_{4} \mathrm{ClS} \\ \text { 6h: } \mathrm{R}=\mathrm{C}_{8} \mathrm{H}_{3} \mathrm{Cl}_{2} \mathrm{~S} & \text { 7h: } \mathrm{R}=\mathrm{C}_{8} \mathrm{H}_{3} \mathrm{Cl}_{2} \mathrm{~S}\end{array}$

${ }^{a}$ Reagents and conditions: (a) CDI, 4-DMAP, THF, reflux, 48 h; (b) TFA, RT, 30 min; (c) 6a-h, DIPEA, THF, $0{ }^{\circ} \mathrm{C}$ to reflux, and 2 h.

three major metabolites in human plasma. ${ }^{44}$ As CBG was also reported to possess a higher TNF- $\alpha$ production-inhibitory activity $(80 \%)$ than thalidomide $(32 \%)$ at concentrations of 3 $\mu \mathrm{M},{ }^{44,45}$ it is of great pharmacological interest, but its mode of interaction remained elusive so far. ${ }^{46}$ During the course of this study, we obtained a crystal structure of CBG in the complex with a humanized mutant form of MsCI4 (Figures 3 and 4). This structure was the result of a cocrystallization trial of this mutant with thalidomide, which aimed at the characterization of the mutant protein. However, the mutant selectively bound CGB that was presumably present in traces in our crystallization setup with thalidomide. This mutant has a number of nonconserved residues in the direct vicinity of the thalidomide-binding pocket mutated to the residues in the human protein, including the substitution $\mathrm{F} 56 \mathrm{H}$. While this residue is not directly involved in classical IMiD binding in $\mathrm{MsCI} 4$ or the human protein, it plays 
an important role in the binding of CBG: together with N50, it coordinates one oxygen of the carboxyl group in the CBGprotruding moiety; the other oxygen of this carboxyl coordinates the conserved water molecule bound to W99. However, in contrast to the hydrolysis products of the succinimide-based compounds $\mathbf{4 a}, \mathbf{4 b}$, and $\mathbf{5 a}$, the amide moiety resulting from ring opening is not found to be involved in defined hydrogen bonding-although superposing approximately with the phthaloyl moiety of thalidomide, it does not form the canonical hydrogen bond with $\mathrm{N50}$, as the latter is engaged in the hydrogen bond to the carboxyl group.

Rational Design of Novel Succinimide Effectors Guided by Hydrolyzed Metabolites. In a next step, we aimed to exploit our knowledge on the binding mode of hydrolyzed metabolites for the design of novel effectors. The fact that the hydrolysis products were selected against their parent compounds in several cocrystallization or soaking experiments suggested that they pose binders of similar, if not superior affinity. Comparing the binding modes of CBG and hydrolyzed $\mathbf{4 a}, \mathbf{4 b}$, and $\mathbf{5 a}$, we further hypothesized that the difference seen for the hydrogen bonding of their amide linkers should yield increased affinity for succinimide-based effectors. Consequently, we used this amide linker to connect different functional groups as protruding moieties to succinimide as the binding moiety. To this aim, we prepared derivatives $7 \mathbf{a}-7 \mathbf{h}$, as shown in Scheme 2, by treating imide $\mathbf{3 a}$ with the corresponding acyl chlorides $\mathbf{6 a -}$ 6h and $N, N$-diisopropylethylamine (DIPEA) in THF.

All derivatives of this second panel were tested in the FRET assay. Only for compound 7e, with a 3,5-dinitrobenzol group, the affinity was decreased under the detectable levels of the FRET assay. For the compounds with an isobutylene (7a), benzyl (7b), or chlorobenzothiophene group $(7 \mathbf{g})$ as the protruding moiety, binding was well detectable but could not be quantified $\left(K_{\mathrm{i}}>40 \mu \mathrm{M}\right)$. Better binding was observed for compounds with a styryl (7f) and dichloro-benzothiophene (7h) group, both showing $K_{\mathrm{i}}$ values of $20 \mu \mathrm{M}$ (Figure 5A). Finally, the highest affinities were achieved with a 2,4,6trichlorobenzol moiety $\left(7 \mathrm{c}, K_{\mathrm{i}}=9 \mu \mathrm{M}\right)$ and benzyloxy group $\left(7 \mathrm{~d}, K_{\mathrm{i}}=4 \mu \mathrm{M}\right)$, rendering $7 \mathrm{~d}$, the highest-affinity binder in this study, with a $K_{\mathrm{i}}$ value comparable to an unmodified succinimide $^{36}$ (Figure 5A).

We continued with characterizing the binding modes of compounds $7 \mathbf{a}-\mathbf{c}$ and $7 \mathrm{f}$ via crystallography. For the best binder $\mathbf{7 d}$, we performed cocrystallization screening, which yielded a new crystal form diffracting to $1.1 \AA$ resolution; the other compounds were successfully evaluated in soaking experiments. All compounds revealed the expected binding mode as observed for the hydrolyzed metabolites of $\mathbf{4 a}, \mathbf{4 b}$, and $\mathbf{5 a}$, with the succinimide moiety forming the canonical interaction within the binding pocket, and the amide linker forming the hydrogen bond with N50. Besides these hydrogen bonds of the binding and linking moiety, no defined interactions with the protein were found for the protruding moieties of any of the five compounds, including the best binder $7 d$. Figure 6 shows a superposition of the compounds of this panel and their conserved binding mode in the aromatic cage.

Based on these data, we hypothesized that the planar benzene connected via an oxygen as in $\mathbf{7 d}$ is favorable for the affinity. Consequently, we designed a third panel of derivatives carrying this feature based on succinimide and glutarimide (Figure 5B). In this panel, in addition to affinity improvement, we also sought to increase the solubility in water via additional polar or charged groups. As described in Scheme 3, reaction of the intermediates
A

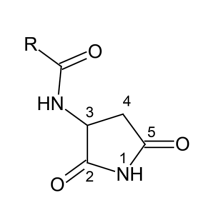<smiles>[R]C(=O)N[C@H]1CC(=O)NC1=O</smiles><smiles>[R]C(=O)N[C@H]1CCC(=O)NC1=O</smiles>
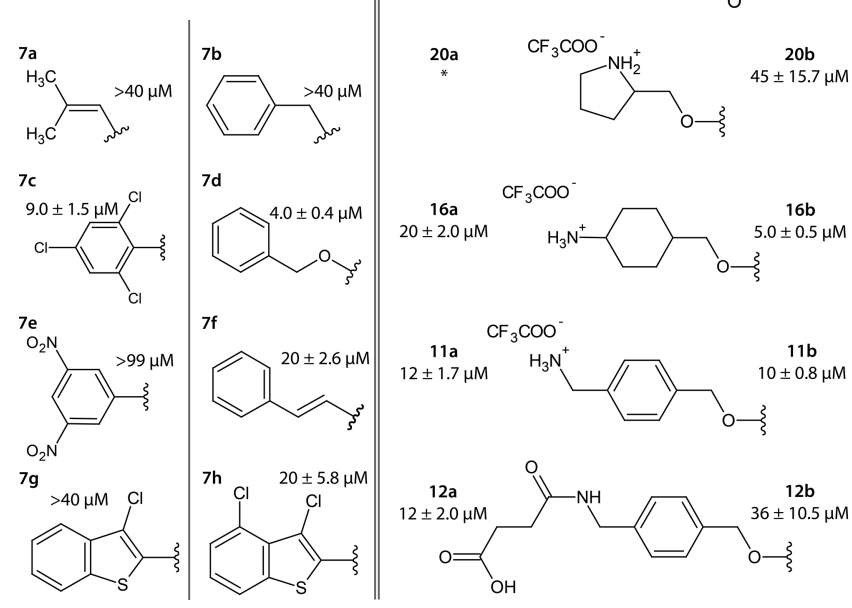

Figure 5. Compounds inspired by hydrolysis products of thalidomide analogues and their affinity data. (A) Second panel of compounds, based on the 3-amidosuccinimide scaffold. (B) Third panel of compounds, inspired by $\mathbf{7 d}$. $* 20$ a could not be purified to satisfactory levels for affinity testing.

8,13 , and 17 with phosgene solution ( $15 \mathrm{wt} \%$ in toluene) in THF yielded to the corresponding chloroformates $9, \mathbf{1 4}$, and 18 . Derivatives 11a, 11b, 16a, 16b, 20a, and 20b were prepared by a coupling reaction between the imides $3 a$ or $3 b$ and the aforementioned chloroformates $\mathbf{9}, \mathbf{1 4}$, and 18 using DIPEA in THF followed by deprotection using TFA. Treatment of the derivatives 11a and $11 \mathbf{b}$ with succinic anhydride and triethylamine $\left(\mathrm{Et}_{3} \mathrm{~N}\right)$ in DMF produced the molecules $12 \mathbf{a}$ and $\mathbf{1 2} \mathbf{b}$, respectively.

Indeed, the final compounds with terminal amino groups were water-soluble (11a, 11b, 16a, 16b), while 12a and 12b, with a terminal succinyl group, were highly soluble in bicarbonate buffer (>200 mM). The compounds were subsequently tested in the FRET assay, apart from 20a, which still contained impurities (see Methods). The assay indicated that all derivatives retained high affinity for CRBN independent of the binding moiety and planarity of the substituent; a clear preference for either binding moiety was not recognizable.

In soaking experiments, we obtained crystal structures with the 5-ring members 11a, 12a, and 20a, and the 6-ring members $16 \mathrm{~b}$, and $20 \mathrm{~b}$, all forming the canonical interactions within the aromatic cage. As expected, the 5-ring effectors form the interaction of the amide linker with N50, which is also observed in one instance for the 6-ring effector $16 \mathbf{b}$. Further interactions of the protruding moieties are not observed for any of the compounds. Consequently, the prolonged extensions are less resolved in the electron density map, which is especially evident for 12a (Figure 7). As these prolonged compounds still retain high affinity, this confirms that the amidosuccinimide scaffold can serve as the universal CRBN-binding moiety, allowing great chemical variability on the protruding moiety.

Degradation of Neo-Substrates. After assessing the biophysical and structural parameters of our designs, we tested their potential for the degradation of neo-substrates in the MMderived human cell line OPM-2. To this end, we have selected the established neo-substrates IKZF3, which is targeted via a 

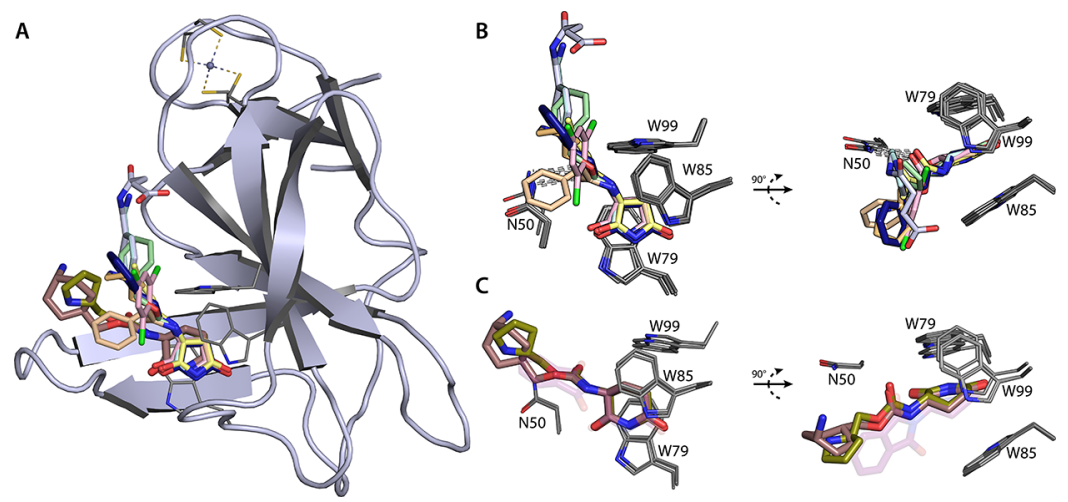

Figure 6. Binding modes of compounds from the second and third panel. (A) Superposition of all compounds bound to MsCI4. (B) Detailed side and top view of bound effectors based on the 3-amidosuccinimide scaffold: 7a (yellow, PDB 6R1X), 7b (sand, PDB 6R12), 7c (pink, PDB 6R1K), 7d (green, PDB 6R1D), 7f (blue, PDB 6R13), and the water soluble 11a (cyan, PDB 6R18), and 12a (light blue, PDB 6R1C), indicating interactions with N50. (C) Side and top view of compounds based on 3-amidoglutarimide, 16b (brown, PDB 6R1W) and 20b (dark green, PDB 6R1A). Although the depicted instances for this scaffold do not show the interaction with N50, this interaction was observed in one other instance for $\mathbf{1 6 b}$.

\section{Scheme $3^{a}$}

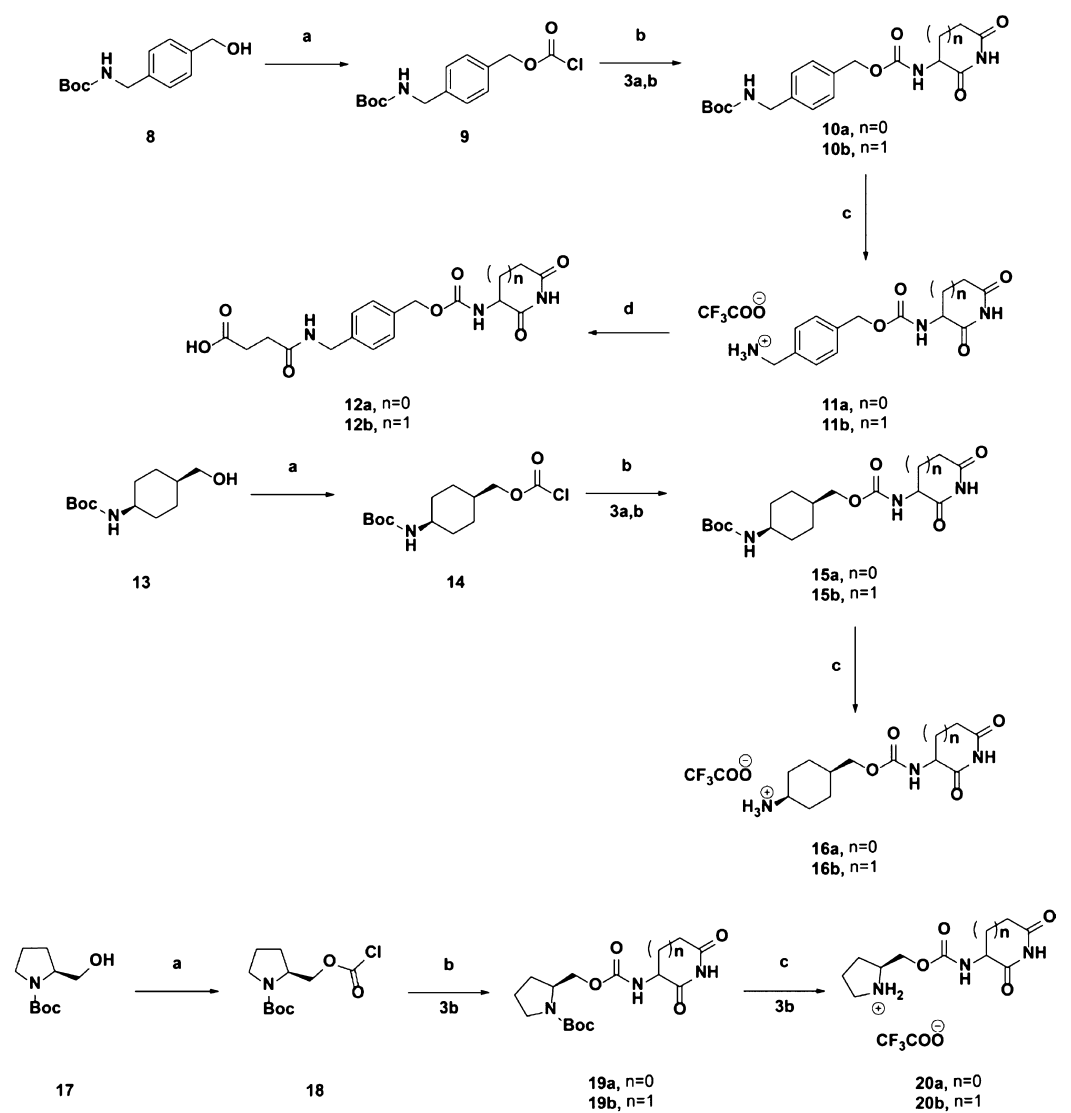

${ }^{a}$ Reagents and conditions: (a) Phosgene solution $15 \mathrm{wt} \%$ in toluene, THF, $0{ }^{\circ} \mathrm{C}$ to RT, $20 \mathrm{~h}$; (b) $3 \mathrm{a}$ or $3 \mathbf{b}$, DIPEA, THF, $0{ }^{\circ} \mathrm{C}$ to reflux, $20 \mathrm{~h}$; (c) TFA, DCM, $0{ }^{\circ} \mathrm{C}$ to RT, $2 \mathrm{~h}$; (d) $\mathrm{Et}_{3} \mathrm{~N}, \mathrm{DMF}, 0{ }^{\circ} \mathrm{C}$ to $\mathrm{RT}, 20 \mathrm{~h}$. Note that $\mathbf{1 3}$ and thereby also $\mathbf{1 4 - 1 6}$ are in cis conformation.

variety of IMiDs ${ }^{20,47-49}$ and $\mathrm{CK} 1 \alpha$, which is so far only targeted via lenalidomide, ${ }^{21}$ as two complementary targets. We treated OPM- 2 cells for $24 \mathrm{~h}$ with the different compounds and assayed for the endogenous levels of both neo-substrates; for comparison, the classical IMiDs, thalidomide, lenalidomide, and pomalidomide were included in the test set. As anticipated, the results for the two neo-substrates were very different. None of the marketed IMiDs apart from lenalidomide was able to reduce the levels of CK1 $\alpha$ significantly, ${ }^{21}$ but also none of our compounds showed any effect on CK1 $\alpha$. This indicates that our compounds could neither supersede nor sufficiently mimic the interface for $\mathrm{CK} 1 \alpha$ recruitment formed by lenalidomide, substantiating the notion of a very narrow specificity window for this substrate. ${ }^{21}$

However, the situation was completely different for IKZF3. Here, in addition to all classical IMiDs, multiple of our designs were successful: significant effects were observed for $\mathbf{5 a}, \mathbf{7 d}$, and $7 \mathrm{f}$, which are all compounds with a rather compact structure from our first and second panel (Figure 8). The only successful compound from the first, phthaloyl-based panel, 5a, represents a 


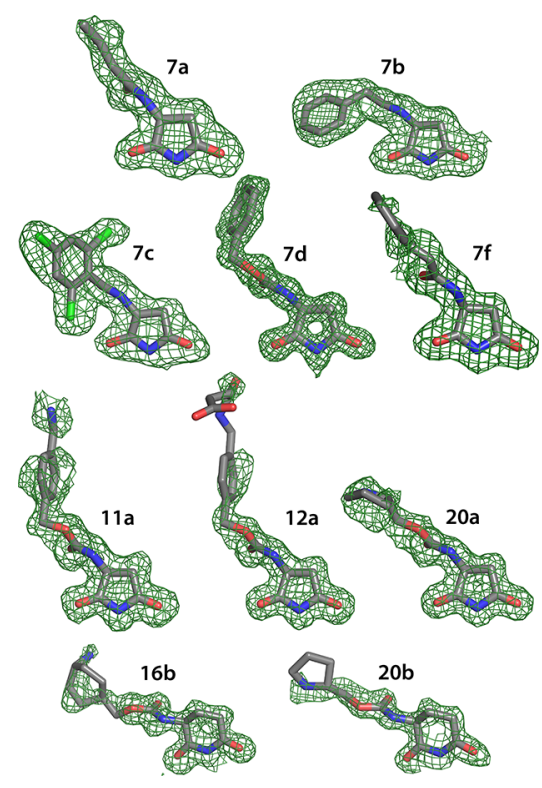

Figure 7. $\mathrm{F}_{\mathrm{O}}-\mathrm{F}_{\mathrm{C}}$ maps of bound compounds shown in Figure 6. All compounds are clearly defined by their electron density maps with the exception of the prolonged extension in 12a. Crystallographic structures were refined to resolutions between 1.1 and $1.8 \AA$, and the maps are contoured at $2 \sigma$. PDB accession codes are 6R1X (7a), 6R12 (7b), 6R1K (7c), 6R1D (7d), 6R13 (7f), 6R18 (11a), 6R1C (12a), 6R1W (16b), 6R19 (20a), and 6R1A (20b).

\begin{tabular}{|c|c|c|c|c|c|c|c|c|c|}
\hline \multirow[t]{2}{*}{ A } & $\begin{array}{l}\text { DMSO } \\
\text { control }\end{array}$ & $\begin{array}{c}7 d \\
100 \mu N\end{array}$ & & $\begin{array}{c}5 a \\
100 \mu N \\
\end{array}$ & & & $\begin{array}{c}7 f \\
100 \mu \mathrm{M}\end{array}$ & & $\begin{array}{c}\text { lenalidomide } \\
20 \mu \mathrm{M}\end{array}$ \\
\hline & $-\infty$ & $-\infty$ & $-1=$ & $=$ & - & $=$ & - & - & --- \\
\hline
\end{tabular}

B

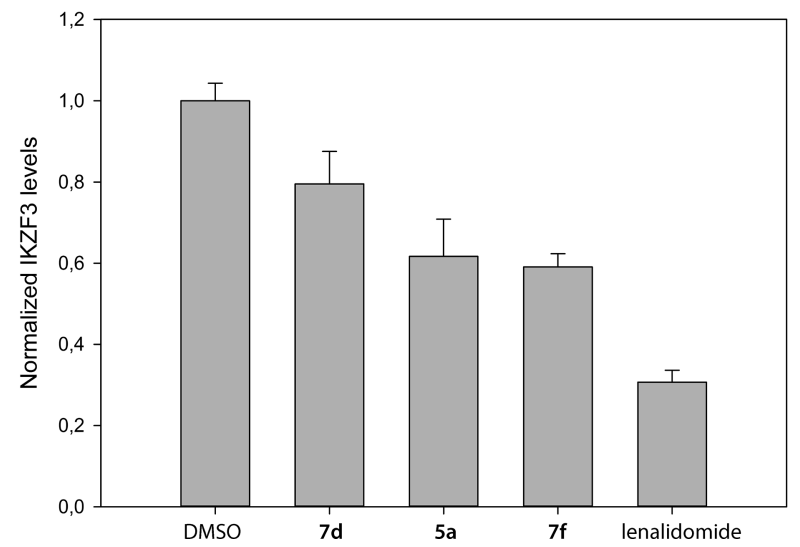

Figure 8. Compound-mediated IKFZ3 degradation in OPM-2 cells. (A) Immunoblot analysis of IKZF3 levels after treatment with compounds $\mathbf{7 d}$, 5a, and $7 \mathrm{f}(100 \mu \mathrm{M})$ for $24 \mathrm{~h}$, compared to DMSO (control) and lenalidomide $(20 \mu \mathrm{M})(n=3)$. Lenalidomide at $100 \mu \mathrm{M}$ reduced IKFZ3 levels effectively by $100 \%$ (not shown). (B) Averaged IKZF3 levels from the three independent experiments, normalized against total protein loading control (Figure S2). The significance of the data was tested comparing IKZF3 levels in the presence of the compounds and DMSO $(p>0.05)$.

direct succinimide analogue of pomalidomide. It reduced IKZF3 levels by almost $40 \%$. Comparison of its structural binding mode to that of thalidomide or pomalidomide already suggested that it may be a possible functional substitute for pomalidomide. The fact that the other compounds of that panel did not show similar effects indicate that substitutions larger than an amino group in the $\mathrm{R}^{2}$ position of the phthaloyl moiety, as for $4 \mathrm{a}$ and $4 \mathrm{c}$, or any substitution in $\mathrm{R}^{1}$, as for $\mathbf{4 b}, \mathbf{4 d}$, and $\mathbf{5 b}$, abolish IKZF3 recruitment.

Most interesting is the analysis of the successful compounds of the second panel, $7 \mathbf{d}$ and $7 \mathbf{f}$, which are not derived from classical IMiDs but from the hydrolysis products of the first panel. $7 \mathrm{~d}$, which is also the highest affinity binder in this study, reduced IKZF3 levels by about $20 \%$. Moreover, the analogous $7 \mathbf{f}$, which is a weaker binder that only differs from $\mathbf{7 d}$ in one heavy atom in the linker, reduced IKZF3 levels by even $40 \%$. Both compounds are more flexible and elongated than 5a, so it appears impossible that their protruding moieties adopt a conformation mimicking the classical IMiDs at the interface between CRBN and IKZF3. Their terminal benzyl groups inevitably project further away from the thalidomide-binding pocket, requiring another mode of interaction with the zinc finger motif than characterized for classical IMiDs. ${ }^{26}$ This interaction mode is also very sensitive to chemical changes: shortening of the linker by only one atom, as for $7 \mathbf{b}$, further modifications on the benzyl group, as for 11a or 12a, or any other variant we designed in the second or third panel abolished IKZF3 recruitment, which is indicative for a highly specific interaction. Therefore, $\mathbf{7 d}$ and $\mathbf{7 f}$ are the first representatives of a novel type of CRBN effectors with a recognition mode that is clearly distinct from that of the classical thalidomide-based IMiDs.

\section{CONCLUSIONS}

The development of CRBN effectors is a rapidly growing field, and novel IMiDs and PROTACS are reported frequently. To date, essentially all of these compounds are based on the classical thalidomide scaffold, which significantly restrains the chemical space available for the recruitment of neo-substrates. Here, following on from our previous characterization of CRBNbinding moieties, we have probed the chemical space for the linking and protruding moiety, taking advantage of the structural binding modes of hydrolyzed metabolites. Although not in the focus of this work, the apparent specificity of CRBN for these hydrolysis products, especially for the major thalidomide metabolite $\mathrm{CBG}$, may inspire further research toward the understanding of their pharmacological relevance.

As a consensus from the binding modes of our initial designs and their hydrolysis products, we derived an amidosuccinimide scaffold as a minimal binding and linking moiety. 3Amidosuccinimide can be used to mount almost arbitrary chemistry as the protruding moiety, while retaining affinities to CRBN in the range of classical IMiDs, rendering it an attractive CRBN-binding moiety for future PROTACS.

However, the most relevant aspect of our study concerns the versatility of the 3-amidosuccinimide scaffold for the design of IMiD-like CRBN effectors. As a minimal binding and linking moiety, it does not restrain the chemical space of protruding moieties, allowing for the design of substrate-recruiting motifs that cannot be realized on a classical IMiD scaffold. In our attempt to probe the effect of different protruding moieties mounted on the amidosuccinimide scaffold, two out of twelve compounds were able to recruit the neo-substrate IKZF3 without further optimization. Although we do not have structural insight into the IKZF3-recognition mode of these effectors, it is clearly incompatible with that of the classical IMiDs, which points at a large unexplored chemical space for the recruitment of new therapeutic targets. For the ongoing characterization of the proteome druggable via the IMiD approach, novel CRBN effectors are needed both for probing 
the space of neo-substrates, as well as for future pharmacological exploitation. With this work, we contribute first steps toward the rational design of a post-thalidomide generation of such effectors, toward unlocking the full potential of the IMiD approach.

\section{EXPERIMENTAL SECTION}

Chemistry. General Procedures. Room temperature (RT) refers to $22{ }^{\circ} \mathrm{C}$. Reagents and anhydrous solvents were transferred via an ovendried syringe or a cannula. Flasks were flame-dried under vacuum and cooled under a constant stream of argon. Anhydrous solvents (toluene, dioxane, and DMF) were purchased from Sigma-Aldrich (anhydrous over molecular sieves). THF was dried over potassium. All other chemicals were purchased from ABCR, Acros, Alfa Aesar, Fluorochem, Merck, Sigma-Aldrich, and TCI Europe at highest commercially available purity and used without further purification. Compound $\mathbf{2 b}$ and $\mathbf{3 b}$ were prepared according to the procedures reported by Capitosti et al. ${ }^{50}$ Compounds 8, 13, and 17 were prepared according to the procedures previously reported. ${ }^{51-54}$ Thin-layer chromatography (TLC) was performed on Merck silica gel 60 F 254 TLC aluminium sheets and visualized by ultraviolet light $(254 \mathrm{~nm})$ and/or with ceric ammonium molybdate, potassium permanganate, or ninhydrine staining solution. Flash column chromatography was performed on Acros silica gel 35-70, $60 \AA$, using a forced flow of eluent (method of Still). Yields refer to chromatographically purified and spectroscopically pure compounds. NMR spectra were recorded on Varian Mercury plus 400 (operating at $400 \mathrm{MHz}$ for ${ }^{1} \mathrm{H}$ and $100 \mathrm{MHz}$ for ${ }^{13} \mathrm{C}$ acquisitions), and Varian Mercury plus 300 (operating at $300 \mathrm{MHz}$ for ${ }^{1} \mathrm{H}$ and 75 $\mathrm{MHz}$ for ${ }^{13} \mathrm{C}$ acquisitions). Chemical shifts are reported in ppm with the solvent resonance as the internal standard $\left(d_{1}\right.$-chloroform: $7.26\left({ }^{1} \mathrm{H}\right.$ NMR), 77.16 ( $\left.{ }^{13} \mathrm{C} \mathrm{NMR}\right) ; d_{6}$-dimethylsulfoxide: 2.50 ( $\left.{ }^{1} \mathrm{H} \mathrm{NMR}\right)$, 39.52 ( ${ }^{13} \mathrm{C}$ NMR); ( $d_{4}$-methanol: 3.31 ( ${ }^{1} \mathrm{H}$ NMR $), 49.00\left({ }^{13} \mathrm{C} \mathrm{NMR}\right)$; [ $d_{6}$-acetone: 2.05 ( $\left.{ }^{1} \mathrm{H} \mathrm{NMR}\right)$, and $29.84,206.26$ ( $\left.\left.{ }^{13} \mathrm{C} \mathrm{NMR}\right)\right]$. Coupling constants $\mathrm{J}$ are reported in Hertz $(\mathrm{Hz})$. Multiplicities are indicated by $\mathrm{s}=$ singlet, $\mathrm{d}=$ doublet $\mathrm{t}=$ triplet, $\mathrm{q}=$ quartet, $\mathrm{sep}=$ septet, $\mathrm{dd}=$ doublet of doublet, $\mathrm{dt}=$ doublet of triplet, $\mathrm{m}=$ multiplet, and $\mathrm{br}=$ broad resonance. High-resolution mass spectra were obtained on Bruker Daltonics ESI-FT-ICR-MS APEX II. IR spectra were measured on ATI/Mattson Genesis FT-IR as thin film (in $\mathrm{CCl}_{4}$ ) or $\mathrm{KBr}$-disk. Absorbance frequencies are reported in reciprocal centimeters $\left(\mathrm{cm}^{-1}\right)$. Melting points were measured on a Boetius-micro hot stage and are uncorrected. The purity of compounds was analyzed by detecting UV absorbance at $254 \mathrm{~nm}$ using a Poroshell 120 EC-C 18 column on a 1260 Infinity II system (Agilent Technologies, Inc.) (Figure S1). All compounds showed $>95 \%$ purity with the exception of $7 \mathbf{a}(87.6 \%)$, $7 \mathbf{b}$ (91.5\%), 7c (88.2\%). 12a (89.4\%), 12b (88.2\%), and 20a (<50\%).

General Procedure A. Preparation of the compounds $4 \mathbf{a}-\mathbf{d}$ : to a solution of $3 \mathbf{a}$ or $3 \mathbf{b}$ (1.0 equiv) in anhydrous THF $(4.60 \mathrm{~mL} / \mathrm{mmol})$, 4nitrophthalic anhydride (1.5 equiv) in anhydrous THF $(0.5 \mathrm{~mL} / \mathrm{mmol})$ was added. CDI (1.7 equiv), $\mathrm{Et}_{3} \mathrm{~N}$ (2.9 equiv), and catalytic amounts of 4-DMAP were added, and the reaction mixture was heated to reflux for $5 \mathrm{~h}$. The solvent was evaporated, and the resulting crude oil was purified by column chromatography to give $\mathbf{4 a}-\mathbf{d}$.

General Procedure $B$. Reduction of the nitro group: to a solution of $4 \mathbf{a}$ or $4 \mathbf{b}$ (1.0 equiv) in EtOAc $(100 \mathrm{~mL} / \mathrm{mmol}), 10 \mathrm{wt} \% \mathrm{Pd} / \mathrm{C}(27 \mathrm{~mol}$ $\%)$ was added. The flask was degassed and let to stir under a hydrogen atmosphere for $20 \mathrm{~h}$ at RT. After completion of the reaction (TLC control), the mixture was filtered over Celite and washed with copious amounts of acetone. Afterward, the solvent was evaporated and $\mathbf{5 a}$ or $\mathbf{5 b}$ was obtained.

General Procedure C. Preparation of the compounds $7 \mathbf{a}-\mathbf{h}$ (amide bond formation): to a solution of the TFA-salt $3 a$ (1.0 equiv) in THF ( 5 $\mathrm{mL} / \mathrm{mmol}$ ), DIPEA (2.0 equiv) was added. The mixture was cooled down to $0{ }^{\circ} \mathrm{C}$, the acyl chloride $\mathbf{6 a}-\mathbf{h}(1.0$ equiv) was added, and the reaction mixture was left to stir under reflux for $2 \mathrm{~h}$. Upon completion, the reaction was diluted with EtOAc and washed with $3 \mathrm{M} \mathrm{HCl}$ and brine. The organic layer was dried over $\mathrm{Na}_{2} \mathrm{SO}_{4}$, and the solvent was evaporated in vacuo. The resulting crude product was purified by flash column chromatography to give $7 \mathbf{a}-\mathbf{h}$.
General Procedure D. Phosgenation, carbamate formation, and Boc deprotection: to a $15 \%$ wt solution of $\mathrm{COCl}_{2}$ in toluene (1.3 equiv) was added dry THF $(0.58 \mathrm{~mL} / \mathrm{mmol})$ under argon. The solution was cooled to $0{ }^{\circ} \mathrm{C}$, and a solution of 8,13 , or 17 (1.0 equiv) in dry THF $(0.6 \mathrm{~mL} / \mathrm{mmol})$ was added over $10 \mathrm{~min}$. The reaction mixture was stirred at $0{ }^{\circ} \mathrm{C}$ for $15 \mathrm{~min}$ and then warmed up to RT and stirred for two more hours. After completion of the reaction, the volatiles were completely evaporated under reduced pressure to give the chloroformates 9,14 , or 18, respectively, which were used for the next step without further purification. To a stirred suspension of the TFA-salt 3a or $3 \mathbf{b}$ ( 1.03 equiv) in dry THF $(2 \mathrm{~mL} / \mathrm{mmol})$, DIPEA $(0.35 \mathrm{~mL} /$ $\mathrm{mmol}$ ) was added at $0{ }^{\circ} \mathrm{C}$. Then, a solution of the chloroformate 9,14 , or 18 (1.0 equiv) in dry THF $(0.35 \mathrm{~mL} / \mathrm{mmol})$ was added gradually to the suspension. The reaction was warmed up to RT, stirred for $30 \mathrm{~min}$ at RT, and then refluxed overnight. After completion of the reaction, the solvent was evaporated, and the crude product was purified by column chromatography giving the carbamates $10 a-b, 15 a-b$, or 19 respectively. To a solution of $10 a-b, 15 a-b$, or 19 (1.0 equiv) in DCM $(4.5 \mathrm{~mL} / \mathrm{mmol})$, TFA (30.0 equiv) was added at $0{ }^{\circ} \mathrm{C}$. The reaction solution was warmed up to RT and stirred for $2 \mathrm{~h}$. After completion of the reaction, the volatiles were completely evaporated to give $11 a-b, 16 a-b$, or 20 respectively.

General Procedure E. Preparation of $\mathbf{1 2 a - b}$ (amide bond formation): derivatives $\mathbf{1 1} \mathbf{a}-\mathbf{b}$ (1.0 equiv) were dissolved in DMF $(2.8 \mathrm{~mL} / \mathrm{mmol})$, and $\mathrm{Et}_{3} \mathrm{~N}$ (2.2 equiv) was added at $0{ }^{\circ} \mathrm{C}$. After $20 \mathrm{~min}$ of stirring, succinic anhydride (1.0 equiv) was added, and the reaction mixture was stirred at RT overnight. After the end of the reaction, the solvent was evaporated, and the corresponding acid $12 \mathbf{a}-\mathbf{b}$ was afforded via flash column chromatography.

tert-Butyl (S)-(2,5-Dioxopyrrolidin-3-yl)carbamate (2a). A mixture of $\mathrm{N}$-Boc-L-asparagin ( $2 \mathrm{~g}, 8.61 \mathrm{mmol}, 1$ equiv), CDI (1.39 g, 8.61 mmol, 1 equiv), and catalytic amounts 4-DMAP in anhydrous THF $(21.5 \mathrm{~mL})$ was stirred and heated to reflux for $48 \mathrm{~h}$. After the end of the reaction, the solvent was evaporated, and the crude product was purified by column chromatography ( $n$-hexane/ethyl acetate, $1: 1 \mathrm{v} / \mathrm{v}$ ) to give $2 \mathrm{a}(1.54 \mathrm{~g}, 6.75 \mathrm{mmol}, 78 \%)$ as a colorless solid. TLC ( $n$ hexane/EtOAc, 3:7 v/v): $R_{\mathrm{f}}=0.48$; mp $160-162{ }^{\circ} \mathrm{C}$; IR (KBr) $\tilde{\nu}_{\max }$ : 3376.75, 3361.32, 1709.59, 1521.56, $1171.54 \mathrm{~cm}^{-1}$; ${ }^{1} \mathrm{H}$ NMR (400 MHz, DMSO- $\left.d_{6}\right): \delta 11.18(\mathrm{~s}, 1 \mathrm{H}), 7.42(\mathrm{~d}, J=8.1 \mathrm{~Hz}, 1 \mathrm{H}), 4.33-4.24$ $(\mathrm{m}, 1 \mathrm{H}), 2.85(\mathrm{dd}, J=17.5,9.4 \mathrm{~Hz}, 1 \mathrm{H}), 2.44(\mathrm{dd}, J=17.5,5.7 \mathrm{~Hz}, 1 \mathrm{H})$, 1.37 (s, 9H); ${ }^{13} \mathrm{C}$ NMR (101 MHz, DMSO): $\delta 178.2,176.5,155.2$, 78.8, 50.3, 36.4, 28.2; HRMS ESI $(m / z):[\mathrm{M}+\mathrm{Na}]^{+}$calcd for $\mathrm{C}_{9} \mathrm{H}_{14} \mathrm{~N}_{2} \mathrm{O}_{4} \mathrm{Na}^{+}, 237.08513$; found, 237.08513 .

2,5-Dioxopyrrolidin-3-aminium 2,2,2-Trifluoroacetate (3a). Compound $3 \mathrm{a}(1.54 \mathrm{~g}, 6.75 \mathrm{mmol}, 1$ equiv) was dissolved in TFA $(7.8 \mathrm{~mL}$, $101.25 \mathrm{mmol}, 15$ equiv) and stirred for $30 \mathrm{~min}$. The excess of the acid was removed in vacuo, and the resulting product was dried under vacuum to give $3 \mathrm{a}(1.54 \mathrm{~g}, 6.75 \mathrm{mmol}$, quant) as an off-white solid. TLC (EtOAc): $R_{\mathrm{f}}=0.0 ; \mathrm{mp} 109-114{ }^{\circ} \mathrm{C}$; IR (KBr) $\tilde{\nu}_{\max }: 3446.17,1665.23$, $1617.02,1593.88,1207.22,1181.19,1149.37,1137.8,723.175 \mathrm{~cm}^{-1}$; ${ }^{1} \mathrm{H}$ NMR (400 MHz, DMSO- $\left.d_{6}\right): \delta 11.71(\mathrm{~s}, 1 \mathrm{H}), 8.61(\mathrm{~s}, 3 \mathrm{H}), 4.39-$ $4.26(\mathrm{~m}, 1 \mathrm{H}), 2.95(\mathrm{~d}, J=26.9 \mathrm{~Hz}, 1 \mathrm{H}), 2.61(\mathrm{dd}, J=17.7,5.5 \mathrm{~Hz}, 1 \mathrm{H})$; ${ }^{13} \mathrm{C}$ NMR (101 MHz, DMSO- $\left.d_{6}\right): \delta 175.29,175.14,158.69$ (q, $J=31.8$ $\mathrm{Hz}), 117.08(\mathrm{q}, J=298.4 \mathrm{~Hz}), 48.53,34.73 ;{ }^{19} \mathrm{~F}$ NMR $(377 \mathrm{MHz}$, DMSO- $\left.d_{6}\right): \delta-73.84$; HRMS ESI $(\mathrm{m} / z):[\mathrm{M}+\mathrm{H}]^{+}$calcd for $\mathrm{C}_{4} \mathrm{H}_{7} \mathrm{~N}_{2} \mathrm{O}_{2}{ }^{+}, 115.05075$; found, 115.05142 .

2-(2,5-Dioxopyrrolidin-3-yl)-4-nitroisoindoline-1,3-dione (4a). Compound $4 \mathrm{a}$ was synthesized according to general procedure A using $3 \mathbf{b}(0.50 \mathrm{~g}, 2.19 \mathrm{mmol})$, 3-nitrophthalic anhydride $(655.7 \mathrm{mg}$, $3.29 \mathrm{mmol}), \mathrm{CDI}(603.2 \mathrm{mg}, 3.72 \mathrm{mmol}), \mathrm{Et}_{3} \mathrm{~N}(0.89 \mathrm{~mL}, 6.35 \mathrm{mmol})$, and catalytic amounts of 4-DMAP. After purification via flash column chromatography ( $n$-hexane/EtOAc, $1: 1 \mathrm{v} / \mathrm{v})$, compound 4a (412 mg, $1.43 \mathrm{mmol} 65 \%$ ) was isolated as a colorless solid. TLC ( $n$-hexane/ EtOAc, $1: 3 \mathrm{v} / \mathrm{v}): R_{\mathrm{F}}=0.72 ; \mathrm{mp} 129-131{ }^{\circ} \mathrm{C}$; IR $(\mathrm{KBr}) \tilde{\nu}_{\max }: 3442.31$, 1722.12, 1541.81, $1396.21 \mathrm{~cm}^{-1} ;{ }^{1} \mathrm{H}$ NMR (400 MHz, acetone- $\left.d_{6}\right): \delta$ 10.55 (br s, $1 \mathrm{H}), 8.35-8.28(\mathrm{~m}, 1 \mathrm{H}), 8.28-8.21(\mathrm{~m}, 1 \mathrm{H}), 8.22-8.15$ $(\mathrm{m}, 1 \mathrm{H}), 5.47(\mathrm{dd}, J=9.7,5.9 \mathrm{~Hz}, 1 \mathrm{H}), 3.21(\mathrm{dd}, J=18.0,9.7 \mathrm{~Hz}, 1 \mathrm{H})$, $3.05(\mathrm{dd}, J=18.0,5.9 \mathrm{~Hz}, 1 \mathrm{H}) ;{ }^{13} \mathrm{C}$ NMR $\left(101 \mathrm{MHz}\right.$, acetone- $\left.d_{6}\right): \delta$ $175.2,174.9,165.9,163.3,146.0,137.4,134.6,129.7,128.0,124.1,49.5$, 
35.2; HRMS ESI $(m / z):[\mathrm{M}+\mathrm{Na}]^{+}$calcd for $\mathrm{C}_{12} \mathrm{H}_{7} \mathrm{~N}_{3} \mathrm{O}_{6} \mathrm{Na}^{+}$, 312.02325; found, 312.04880 .

2-(2,5-Dioxopyrrolidin-3-yl)-5-nitroisoindoline-1,3-dione (4b). Compound $\mathbf{4 b}$ was synthesized according to general procedure $\mathrm{A}$ using 3a (0.5 g, $2.19 \mathrm{mmol})$, 4-nitrophthalic anhydride $(656 \mathrm{mg}, 3.29$ $\mathrm{mmol})$, CDI (603 mg, $3.72 \mathrm{mmol}), \mathrm{Et}_{3} \mathrm{~N}(0.89 \mathrm{~mL}, 6.35 \mathrm{mmol})$, and catalytic amounts of 4-DMAP. After purification via flash column chromatography ( $n$-hexane/EtOAc, $1: 1 \mathrm{v} / \mathrm{v})$ compound $4 \mathbf{b}(483 \mathrm{mg}$, $1.67 \mathrm{mmol} 76 \%$ ) was isolated as a colorless solid. TLC ( $n$-hexane/ EtOAc, $1: 3 \mathrm{v} / \mathrm{v}): R_{\mathrm{F}}=0.61 ; \mathrm{mp} 203-204{ }^{\circ} \mathrm{C}$; IR $(\mathrm{KBr}) \tilde{\nu}_{\text {max }}: 3489.56$, $1787.69,1538.92,1399.1,1349.93,722.211 \mathrm{~cm}^{-1} ;{ }^{1} \mathrm{H}$ NMR $(400 \mathrm{MHz}$, acetone- $\left.d_{6}\right): \delta 10.55(\mathrm{br} \mathrm{s}, 1 \mathrm{H}), 8.75(\mathrm{dd}, J=8.2,2.0 \mathrm{~Hz}, 1 \mathrm{H}), 8.62(\mathrm{dd}$, $J=2.0,0.5 \mathrm{~Hz}, 1 \mathrm{H}), 8.21(\mathrm{dd}, J=8.2,0.5 \mathrm{~Hz}, 1 \mathrm{H}), 5.50(\mathrm{dd}, J=9.7,5.9$ $\mathrm{Hz}, 1 \mathrm{H}), 3.23(\mathrm{dd}, J=18.0,9.7 \mathrm{~Hz}, 1 \mathrm{H}), 3.06(\mathrm{dd}, J=18.0,5.9 \mathrm{~Hz}, 1 \mathrm{H})$; ${ }^{13} \mathrm{C}$ NMR (101 MHz, acetone- $\left.d_{6}\right): \delta 175.2,174.9,166.3,166.0,153.1$, $137.2,134.1,130.8,125.8,119.3,49.5,35.3$; HRMS ESI $(m / z):[\mathrm{M}+$ $\mathrm{Na}+\mathrm{MeOH}]^{+}$calcd for $\mathrm{C}_{13} \mathrm{H}_{11} \mathrm{~N}_{3} \mathrm{O}_{7} \mathrm{Na}^{+}, 344.04947$; found, 344.04985

2-(2,6-Dioxopiperidin-3-yl)-4-nitroisoindoline-1,3-dione (4c). Compound $4 \mathrm{c}$ was synthesized according to the general procedure $\mathrm{A}$ using $3 \mathbf{b}$ (3.11 g, $12.9 \mathrm{mmol})$, 3-nitrophthalic anhydride (3.73 g, 19.3 $\mathrm{mmol})$, CDI (3.55 g, $21.9 \mathrm{mmol}) \mathrm{Et}_{3} \mathrm{~N}(5.2 \mathrm{~mL}, 37.3 \mathrm{mmol})$, and catalytic amounts of 4-DMAP. After purification via flash column chromatography ( $n$-hexane/EtOAc, $1: 1-1: 4 \mathrm{v} / \mathrm{v})$, compound $4 \mathrm{c}(3.48$ $\mathrm{g}, 11.5 \mathrm{mmol}, 89 \%)$ was isolated as a colorless solid. TLC ( $n$-hexane/ EtOAc, $3: 7 \mathrm{v} / \mathrm{v}): R_{\mathrm{F}}=0.40 ;{ }^{1} \mathrm{H}$ NMR $\left(400 \mathrm{MHz}\right.$, DMSO- $\left.d_{6}\right): \delta 11.17$ $(\mathrm{s}, 1 \mathrm{H}), 8.34(\mathrm{dd}, J=8.1,0.7 \mathrm{~Hz}, 1 \mathrm{H}), 8.23(\mathrm{dd}, J=7.5,0.7 \mathrm{~Hz}, 1 \mathrm{H})$, $8.15-8.08(\mathrm{~m}, 1 \mathrm{H}), 5.19(\mathrm{dd}, J=12.9,5.4 \mathrm{~Hz}, 1 \mathrm{H}), 2.88(\mathrm{ddd}, J=17.3$, 13.9, $5.4 \mathrm{~Hz}, 1 \mathrm{H}), 2.61(\mathrm{dt}, J=17.0,2.7 \mathrm{~Hz}, 1 \mathrm{H}), 2.56-2.44(\mathrm{~m}, 1 \mathrm{H})$, $2.08(\mathrm{dtd}, J=12.9,5.3,2.1 \mathrm{~Hz}, 1 \mathrm{H}) ;{ }^{13} \mathrm{C}$ NMR (101 MHz, DMSO): $\delta$ $172.8,169.6,165.3,162.6,144.5,136.9,133.1,129.0,127.4,122.6,49.5$, 30.9, 21.8; HRMS ESI $(m / z):[\mathrm{M}+\mathrm{Na}+\mathrm{MeOH}]^{+}$calcd for $\mathrm{C}_{14} \mathrm{H}_{13} \mathrm{~N}_{3} \mathrm{O}_{7} \mathrm{Na}^{+}$, 358.06512; found, 358.06703; spectral data were consistent with the literature. ${ }^{55}$

2-(2,6-Dioxopiperidin-3-yl)-5-nitroisoindoline-1,3-dione (4d). Compound $\mathbf{4 d}$ was synthesized according to the general procedure $\mathrm{A}$ using 3 b (4.17 g, $17.2 \mathrm{mmol})$, 4-nitrophthalic anhydride (4.99 g, 25.9 $\mathrm{mmol})$, CDI (4.73 g, $29.1 \mathrm{mmol}) \mathrm{Et}_{3} \mathrm{~N}(6.97 \mathrm{~mL}, 50.00 \mathrm{mmol})$, and catalytic amounts of 4-DMAP. After purification via flash column chromatography ( $n$-hexane/EtOAc, $1: 1-1: 4 \mathrm{v} / \mathrm{v})$, compound $4 \mathrm{~d}(2.35$ $\mathrm{g}, 7.8 \mathrm{mmol}, 45 \%)$ was isolated as a colorless solid. TLC ( $n$-hexane/ EtOAc, 3:7 v/v): $R_{\mathrm{f}}=0.50 ;{ }^{1} \mathrm{H}$ NMR $\left(400 \mathrm{MHz}\right.$, DMSO- $\left.d_{6}\right): \delta 11.18$ $(\mathrm{s}, 1 \mathrm{H}), 8.67(\mathrm{dd}, J=8.2,2.0 \mathrm{~Hz}, 1 \mathrm{H}), 8.56(\mathrm{~d}, J=2.0 \mathrm{~Hz}, 1 \mathrm{H}), 8.19(\mathrm{~d}$, $J=8.2 \mathrm{~Hz}, 1 \mathrm{H}), 5.23(\mathrm{dd}, J=12.9,5.4 \mathrm{~Hz}, 1 \mathrm{H}), 2.90(\mathrm{ddd}, J=17.1$, $13.9,5.4 \mathrm{~Hz}, 1 \mathrm{H}), 2.63$ (ddd, $J=17.1,4.3,2.3 \mathrm{~Hz}, 1 \mathrm{H}), 2.58-2.47(\mathrm{~m}$, $1 \mathrm{H}), 2.10(\mathrm{dtd}, J=12.9,5.2,2.2 \mathrm{~Hz}, 1 \mathrm{H}) ;{ }^{13} \mathrm{C}$ NMR $(101 \mathrm{MHz}$, DMSO): $\delta 172.82,169.61,165.63,165.36,151.79,135.80,132.60$, $130.17,125.09,118.46,49.57,30.95,21.91$; HRMS ESI $(\mathrm{m} / z):[\mathrm{M}+$ $\mathrm{Na}+\mathrm{MeOH}]^{+}$calcd for $\mathrm{C}_{14} \mathrm{H}_{13} \mathrm{~N}_{3} \mathrm{O}_{7} \mathrm{Na}^{+}, 358.06512$; found, 358.06642; spectral data were consistent with the literature. ${ }^{50}$

4-Amino-2-(2,5-dioxopyrrolidin-3-yl)isoindoline-1,3-dione (5a). Compound 5a was synthesized according to the general procedure $\mathrm{B}$ using $4 \mathrm{a}(0.30 \mathrm{~g}, 1.04 \mathrm{mmol})$ and $10 \mathrm{wt} \% \mathrm{Pd} / \mathrm{C}(0.30 \mathrm{~g}, 0.28 \mathrm{mmol})$. Compound $5 \mathrm{a}(0.25 \mathrm{~g}, 0.95 \mathrm{mmol}, 92 \%)$ was obtained as a yellow-green solid. TLC ( $n$-hexane/EtOAc, $1: 3 \mathrm{v} / \mathrm{v}): R_{\mathrm{f}}=0.61 ; \mathrm{mp} 292-295^{\circ} \mathrm{C}$; IR $(\mathrm{KBr}) \tilde{\nu}_{\max }: 3474.13,1727.91,1702.84,1632.45 \mathrm{~cm}^{-1}$; ${ }^{1} \mathrm{H}$ NMR (400 MHz, acetone- $\left.d_{6}\right): \delta 10.45($ br s, $1 \mathrm{H}), 7.50(\mathrm{dd}, J=8.4,7.1 \mathrm{~Hz}, 1 \mathrm{H})$, $7.07(\mathrm{dd}, J=10.7,7.7 \mathrm{~Hz}, 2 \mathrm{H}), 6.17(\mathrm{~s}, 1 \mathrm{H}), 5.34(\mathrm{dd}, J=9.7,5.9 \mathrm{~Hz}$, $1 \mathrm{H}), 3.18(\mathrm{dd}, J=17.9,9.7 \mathrm{~Hz}, 1 \mathrm{H}), 3.02(\mathrm{dd}, J=17.9,5.9 \mathrm{~Hz}, 1 \mathrm{H}) ;{ }^{13} \mathrm{C}$ NMR $\left(101 \mathrm{MHz}\right.$, acetone- $\left.d_{6}\right): \delta 175.7,175.5,170.9,170.9,147.8$, 136.4, 133.4, 122.5, 122.4, 112.4, 48.7, 35.6; HRMS ESI $(\mathrm{m} / z):[\mathrm{M}+$ $\mathrm{Na}]^{+}$calcd for $\mathrm{C}_{12} \mathrm{H}_{9} \mathrm{~N}_{3} \mathrm{O}_{4} \mathrm{Na}^{+}, 282.04908$; found, 282.04853 .

5-Amino-2-(2,5-dioxopyrrolidin-3-yl)isoindoline-1,3-dione (5b). Compound $\mathbf{5 b}$ was synthesized according to the general procedure $\mathrm{B}$ using $4 \mathrm{a}(0.30 \mathrm{~g}, 1.0 \mathrm{mmol})$ and $10 \mathrm{wt} \% \mathrm{Pd} / \mathrm{C}(0.30 \mathrm{~g}, 0.3 \mathrm{mmol})$. Compound $\mathbf{5 b}(0.26 \mathrm{~g}, 1.0 \mathrm{mmol}, 97 \%)$ was obtained as a yellow-green solid. TLC ( $n$-hexane/EtOAc, 1:3 v/v): $R_{\mathrm{F}}=0.68 ; \mathrm{mp} 259-260^{\circ} \mathrm{C}$; IR $(\mathrm{KBr}) \tilde{\nu}_{\max }: 3473.17,3354.57,1701.87,1628.59,1613.16,1405.85$ $\mathrm{cm}^{-1}$; ${ }^{1} \mathrm{H}$ NMR $\left(300 \mathrm{MHz}\right.$, acetone- $\left.d_{6}\right): \delta 10.40(\mathrm{br} \mathrm{s}, 1 \mathrm{H}), 7.54(\mathrm{~d}, J=$ $8.2 \mathrm{~Hz}, 1 \mathrm{H}), 7.07(\mathrm{~d}, J=1.8 \mathrm{~Hz}, 1 \mathrm{H}), 6.97(\mathrm{dd}, J=8.2,2.1 \mathrm{~Hz}, 1 \mathrm{H}), 6.00$ (br s, $2 \mathrm{H}), 5.32(\mathrm{dd}, J=9.7,6.0 \mathrm{~Hz}, 1 \mathrm{H}), 3.16(\mathrm{dd}, J=17.9,9.7 \mathrm{~Hz}, 1 \mathrm{H})$, $2.98(\mathrm{dd}, J=17.9,6.0 \mathrm{~Hz}, 1 \mathrm{H}) ;{ }^{13} \mathrm{C}$ NMR $\left(75 \mathrm{MHz}\right.$, acetone- $\left.d_{6}\right): \delta$ 175.8, 175.6, 155.9, 135.6, 126.0, 118.8, 118.4, 108.5, 48.8, 35.6; HRMS ESI $(m / z):[\mathrm{M}+\mathrm{Na}]^{+}$calcd for $\mathrm{C}_{12} \mathrm{H}_{9} \mathrm{~N}_{3} \mathrm{O}_{4} \mathrm{Na}^{+}$, 282.04908; found, 282.04853 .

$\mathrm{N}$-(2,5-Dioxopyrrolidin-3-yl)-3-methylbut-2-enamide (7a). Compound $7 \mathrm{a}$ was synthesized according to the general procedure $\mathrm{C}$ using 3a (0.10 g, $0.44 \mathrm{mmol})$, DIPEA $(0.15 \mathrm{~mL}, 0.88 \mathrm{mmol})$, and 3, 3dimethylacryloyl chloride $6 \mathrm{a}(51.9 \mathrm{mg}, 0.44 \mathrm{mmol})$. After purification via flash column chromatography, ( $n$-hexane/EtOAc, $5: 5 \mathrm{v} / \mathrm{v})$ compound $7 \mathrm{a}(56.8 \mathrm{mg}, 0.29 \mathrm{mmol}, 66 \%)$ was isolated as a colorless solid. TLC $(n$-hexane $/$ EtOAc, $3: 7 \mathrm{v} / \mathrm{v}): R_{\mathrm{f}}=0.18 ; \mathrm{mp} 181-188^{\circ} \mathrm{C}$; IR $(\mathrm{KBr}) \tilde{\nu}_{\max }: 3354.57,1729.83,1715.37,1624.73,1530.24,1363.43$, 1261.22, 1193.72, $1177.33 \mathrm{~cm}^{-1} ;{ }^{1} \mathrm{H}$ NMR $\left(300 \mathrm{MHz}\right.$, acetone- $\left.d_{6}\right): \delta$ $10.04(\mathrm{~s}, 1 \mathrm{H}), 7.63(\mathrm{~s}, 1 \mathrm{H}), 5.72(\mathrm{~s}, 1 \mathrm{H}), 4.54(\mathrm{ddd}, J=9.3,7.5,5.8 \mathrm{~Hz}$, $1 \mathrm{H}), 2.97(\mathrm{dd}, J=17.6,9.3 \mathrm{~Hz}, 1 \mathrm{H}), 2.71(\mathrm{dd}, J=17.6,5.8 \mathrm{~Hz}, 1 \mathrm{H})$, $2.11(\mathrm{~d}, J=1.2 \mathrm{~Hz}, 3 \mathrm{H}), 1.82(\mathrm{~d}, J=1.2 \mathrm{~Hz}, 3 \mathrm{H}) ;{ }^{13} \mathrm{C} \mathrm{NMR}(75 \mathrm{MHz}$, acetone- $\left.d_{6}\right): \delta 176.0,172.1,167.3,152.3,118.6,51.1,37.2,27.1,19.7$; HRMS ESI $(m / z):[\mathrm{M}+\mathrm{Na}]^{+}$calcd for $\mathrm{C}_{9} \mathrm{H}_{12} \mathrm{~N}_{2} \mathrm{O}_{3} \mathrm{Na}^{+}, 219.07456$; found, 219.07401 .

$\mathrm{N}$-(2,5-Dioxopyrrolidin-3-yl)-2-phenylacetamide (7b). Compound $7 \mathbf{b}$ was synthesized according to the general procedure $C$ using $3 \mathbf{a}(0.10$ g, $0.44 \mathrm{mmol})$, DIPEA $(0.15 \mathrm{~mL}, 0.876 \mathrm{mmol})$, and phenylacetyl chloride $6 \mathbf{b}(67.7 \mathrm{mg}, 0.44 \mathrm{mmol})$. After purification via flash column chromatography ( $n$-hexane/EtOAc, $1: 1 \mathrm{v} / \mathrm{v})$, compound $7 \mathbf{b}(75.9 \mathrm{mg}$, $0.33 \mathrm{mmol}, 75 \%)$ was isolated as a colorless solid. TLC ( $n$-hexane/ EtOAc, $3: 7 \mathrm{v} / \mathrm{v}): R_{\mathrm{f}}=0.15$; mp $181-184{ }^{\circ} \mathrm{C}$; IR $(\mathrm{KBr}) \tilde{\nu}_{\max }: 3502.1$, 3259.11, 1731.76, 1715.35, 1654.62, 1542.77, 1358.6, 1196.61, 1172.51 $\mathrm{cm}^{-1}$; ${ }^{1} \mathrm{H}$ NMR (400 MHz, acetone- $\left.d_{6}\right): \delta 10.02(\mathrm{br} \mathrm{s}, 1 \mathrm{H}), 7.81(\mathrm{br} \mathrm{s}$, $1 \mathrm{H}), 7.35-7.18(\mathrm{~m}, 5 \mathrm{H}), 4.57(\mathrm{ddd}, J=9.3,7.5,5.8 \mathrm{~Hz}, 1 \mathrm{H}), 3.56(\mathrm{~s}$, $2 \mathrm{H}), 2.96(\mathrm{dd}, J=17.6,9.4 \mathrm{~Hz}, 1 \mathrm{H}), 2.66(\mathrm{dd}, J=17.6,5.8 \mathrm{~Hz}, 1 \mathrm{H}) ;{ }^{13} \mathrm{C}$ NMR $\left(101 \mathrm{MHz}\right.$, acetone- $\left.d_{6}\right): \delta 176.3,175.0,170.7,135.7,129.2$, 128.3, 126.6, 50.4, 42.2, 36.2; HRMS ESI $(\mathrm{m} / z):[\mathrm{M}+\mathrm{Na}]^{+}$calcd for $\mathrm{C}_{12} \mathrm{H}_{12} \mathrm{~N}_{3} \mathrm{O}_{6} \mathrm{Na}^{+}$, 255.07456; found, 255.07401.

2,4,6-Trichloro- $N$-(2,5-dioxopyrrolidin-3-yl)benzamide (7c). Compound $7 \mathrm{c}$ was synthesized according to the general procedure $\mathrm{C}$ using 3a $(0.10 \mathrm{~g}, 0.438 \mathrm{mmol})$, DIPEA $(0.15 \mathrm{~mL}, 0.88 \mathrm{mmol})$, and 2,4,6-trichlorobenzoyl chloride $6 \mathrm{c}(106.8 \mathrm{mg}, 0.44 \mathrm{mmol})$. After purification via flash column chromatography ( $n$-hexane/EtOAc, $5: 5 \mathrm{v} /$ $\mathrm{v})$, compound $7 \mathrm{c}(81.7 \mathrm{mg}, 0.25 \mathrm{mmol}, 58 \%)$ was isolated as a colorless solid. TLC ( $n$-hexane/EtOAc, 3:7 v/v): $R_{\mathrm{F}}=0.47 ; \mathrm{mp} 210-212{ }^{\circ} \mathrm{C}$; IR $(\mathrm{KBr}) \tilde{\nu}_{\max }: 3450.03,3249.47,1717.3,1640.16,1582.31,1547.59 \mathrm{~cm}^{-1}$; ${ }^{1} \mathrm{H}$ NMR $\left(400 \mathrm{MHz}\right.$, DMSO- $\left.d_{6}\right): \delta 11.35(\mathrm{~s}, 1 \mathrm{H}), 9.37(\mathrm{~d}, J=7.5 \mathrm{~Hz}$, $1 \mathrm{H}), 7.75(\mathrm{~s}, 1 \mathrm{H}), 4.59(\mathrm{ddd}, J=9.3,7.6,5.3 \mathrm{~Hz}, 1 \mathrm{H}), 3.01(\mathrm{dd}, J=17.6$, $9.4 \mathrm{~Hz}, 1 \mathrm{H}), 2.59$ (dd, $J=17.6,5.3 \mathrm{~Hz}, 1 \mathrm{H}) ;{ }^{13} \mathrm{C} \mathrm{NMR}(101 \mathrm{MHz}$, DMSO): $\delta 176.5,176.3,163.3,134.9,134.3,132.3,128.1,50.0,35.9$; HRMS ESI $(m / z):[\mathrm{M}+\mathrm{Na}]^{+}$calcd for $\mathrm{C}_{11} \mathrm{H}_{7} \mathrm{Cl}_{3} \mathrm{~N}_{2} \mathrm{O}_{3} \mathrm{Na}^{+}, 342.94199$; found, 342.94145 .

Benzyl (2,5-Dioxopyrrolidin-3-yl)carbamate (7d). Compound 7d was synthesized according to the general procedure $\mathrm{C}$ using $3 \mathrm{a}(0.10 \mathrm{~g}$, $0.44 \mathrm{mmol})$, DIPEA $(0.15 \mathrm{~mL}, 0.876 \mathrm{mmol})$, and benzyl chloroformate 6d $(74.7 \mathrm{mg}, 0.44 \mathrm{mmol})$. After purification via flash column chromatography ( $n$-hexane/EtOAc, 5:5 v/v), compound $7 \mathrm{~d}(105.9$ $\mathrm{mg}, 0.43 \mathrm{mmol}, 98 \%)$ was isolated as a colorless solid. TLC ( $n$-hexane/ EtOAc, $3: 7 \mathrm{v} / \mathrm{v}): R_{\mathrm{f}}=0.44 ; \mathrm{mp} 93-96{ }^{\circ} \mathrm{C}$; IR $(\mathrm{KBr}) \tilde{\nu}_{\max }: 3363.25$, 1718.26, 1532.17, 1267.97, 1203.36, $1177.33 \mathrm{~cm}^{-1}$; ${ }^{1} \mathrm{H}$ NMR (400 MHz, acetone- $\left.d_{6}\right): \delta 10.09(\mathrm{br} \mathrm{s}, 1 \mathrm{H}), 7.41-7.27(\mathrm{~m}, 5 \mathrm{H}), 7.08(\mathrm{br} \mathrm{s}$, $1 \mathrm{H}), 5.10(\mathrm{~s}, 2 \mathrm{H}), 4.63-4.53(\mathrm{~m}, 1 \mathrm{H}), 3.05(\mathrm{dd}, J=17.6,9.4 \mathrm{~Hz}, 1 \mathrm{H})$, $2.74(\mathrm{dd}, J=17.6,5.5 \mathrm{~Hz}, 1 \mathrm{H}) ;{ }^{13} \mathrm{C}$ NMR $\left(101 \mathrm{MHz}\right.$, acetone- $\left.d_{6}\right): \delta$ $177.5,175.8,156.9,137.8,129.2,128.7,67.1,52.0,37.1$; HRMS ESI $(m / z):[\mathrm{M}+\mathrm{Na}]^{+}$calcd for $\mathrm{C}_{12} \mathrm{H}_{12} \mathrm{~N}_{2} \mathrm{O}_{4} \mathrm{Na}^{+}, 271.06948$; found, 271.06893.

N-(2,5-Dioxopyrrolidin-3-yl)-3,5-dinitrobenzamide (7e). Compound $7 \mathbf{e}$ was synthesized according to the general procedure $\mathrm{C}$ using 3a (0.1 g, $0.44 \mathrm{mmol})$, DIPEA $(0.15 \mathrm{~mL}, 0.88 \mathrm{mmol})$, and 3,5dinitrobenzoyl chloride $6 \mathrm{e}(0.10 \mathrm{~g}, 0.44 \mathrm{mmol})$. After purification via flash column chromatography ( $n$-hexane/EtOAc, $5: 5 \mathrm{v} / \mathrm{v}$ ), compound 7 e $(0.10 \mathrm{~g}, 0.34 \mathrm{mmol}, 76 \%)$ was isolated as a colorless solid. TLC ( $n$ hexane $/$ EtOAc, $3: 7 \mathrm{v} / \mathrm{v}): R_{\mathrm{f}}=0.28 ; \mathrm{mp} 238-239^{\circ} \mathrm{C}$; IR $(\mathrm{KBr}) \tilde{\nu}_{\max }$ : $3447.16,3389.28,1717.3,1659.45,1540.85,1348,1188.9 \mathrm{~cm}^{-1} ;{ }^{1} \mathrm{H}$ 
NMR (400 MHz, acetone- $d_{6}$ ): $\delta 10.24$ (br s, $\left.1 \mathrm{H}\right), 9.15(\mathrm{~d}, J=7.1 \mathrm{~Hz}$, $1 \mathrm{H}), 9.12-9.06(\mathrm{~m}, 3 \mathrm{H}), 4.99-4.91(\mathrm{~m}, 1 \mathrm{H}), 3.20-3.11(\mathrm{~m}, 1 \mathrm{H}), 2.93$ (dd, $J=17.8,5.8 \mathrm{~Hz}, 1 \mathrm{H}) ;{ }^{13} \mathrm{C}$ NMR $(101 \mathrm{MHz}$, acetone): $\delta 176.7$, $175.7,163.7,149.7,137.6,128.3,122.1,51.8,36.8$; HRMS ESI $(\mathrm{m} / z)$ : $[\mathrm{M}+\mathrm{Na}]^{+}$calcd for $\mathrm{C}_{11} \mathrm{H}_{8} \mathrm{~N}_{4} \mathrm{O}_{7} \mathrm{Na}^{+}, 331.02907$; found, 331.02842 .

$\mathrm{N}$-(2,5-Dioxopyrrolidin-3-yl)cinnamamide (7f). Compound $7 \mathbf{f}$ was synthesized according to the general procedure $\mathrm{C}$ using $3 \mathrm{a}(0.10 \mathrm{~g}, 0.44$ $\mathrm{mmol})$, DIPEA $(0.15 \mathrm{~mL}, 0.88 \mathrm{mmol})$, and cinnamoyl chloride $6 \mathbf{f}(73.0$ $\mathrm{mg}, 0.44 \mathrm{mmol})$. After purification via flash column chromatography ( $n$-hexane/EtOAc, 1:1 v/v), compound $7 f(102 \mathrm{mg}, 0.42 \mathrm{mmol}$, 96\%) was isolated as a colorless solid. TLC ( $n$-hexane/EtOAc, $3: 7 \mathrm{v} / \mathrm{v}): R_{\mathrm{f}}=$ 0.19; mp 213-214 ${ }^{\circ} \mathrm{C}$; IR (KBr) $\tilde{\nu}_{\max }: 3431.71,1718.26,2654.62$, 1617.02, $1522.52,1191.79 \mathrm{~cm}^{-1}$; ${ }^{1} \mathrm{H}$ NMR $\left(300 \mathrm{MHz}\right.$, acetone- $\left.d_{6}\right): \delta$ $10.11(\mathrm{~s}, 1 \mathrm{H}), 8.01(\mathrm{~d}, J=6.2 \mathrm{~Hz}, 1 \mathrm{H}), 7.71-7.33(\mathrm{~m}, 6 \mathrm{H}), 6.71(\mathrm{~d}, J=$ $15.8 \mathrm{~Hz}, 1 \mathrm{H}), 4.76-4.63(\mathrm{~m}, 1 \mathrm{H}), 3.10-2.97(\mathrm{~m}, 1 \mathrm{H}), 2.80(\mathrm{dd}, J=$ 17.6, $5.9 \mathrm{~Hz}, 1 \mathrm{H}) ;{ }^{13} \mathrm{C}$ NMR $\left(75 \mathrm{MHz}\right.$, acetone- $\left.d_{6}\right): \delta 177.3,175.9$, $166.4,141.5,136.0,130.5,129.7,128.6,121.5,51.5,37.2$; HRMS ESI $(m / z):[\mathrm{M}+\mathrm{Na}]^{+}$calcd for $\mathrm{C}_{13} \mathrm{H}_{12} \mathrm{~N}_{2} \mathrm{O}_{3} \mathrm{Na}^{+}, 267.07456$; found, 267.07401.

3-Chloro-N-(2,5-dioxopyrrolidin-3-yl)benzo[b]thiophene-2-carboxamide (7g). Compound $7 \mathrm{~g}$ was synthesized according to the general procedure $\mathrm{C}$ using $3 \mathrm{a}(100 \mathrm{mg}, 0.44 \mathrm{mmol})$, DIPEA $(0.15 \mathrm{~mL}$, $0.88 \mathrm{mmol}$ ), and 3-chlorobenzo[b]thiophen-2-carbonyl chloride $\mathbf{6 g}$ $(101 \mathrm{mg}, 0.44 \mathrm{mmol})$. After purification via flash column chromatography ( $n$-hexane/EtOAc, $1: 1 \mathrm{v} / \mathrm{v})$, compound $7 \mathrm{~g}(128 \mathrm{mg}, 0.41 \mathrm{mmol}$, 94\%) was isolated as a colorless solid. TLC ( $n$-hexane/EtOAc, 3:7 v/v): $R_{\mathrm{f}}=0.46$; mp $215-218{ }^{\circ} \mathrm{C}$; IR $(\mathrm{KBr}) \tilde{\nu}_{\text {max }}: 3445.21,2932.23,1729.83$, $1636.3,1534.1 \mathrm{~cm}^{-1}$; ${ }^{1} \mathrm{H}$ NMR (400 MHz, acetone- $\left.d_{6}\right): \delta 10.18$ (br s, $1 \mathrm{H}), 8.47(\mathrm{br} \mathrm{d}, J=6.6 \mathrm{~Hz}, 1 \mathrm{H}), 8.10-7.98(\mathrm{~m}, 1 \mathrm{H}), 8.00-7.90(\mathrm{~m}$, $1 \mathrm{H}), 7.66-7.55(\mathrm{~m}, 2 \mathrm{H}), 4.99(\mathrm{ddt}, J=10.4,7.2,5.2 \mathrm{~Hz}, 1 \mathrm{H}), 3.14$ (ddd, $J=17.7,9.5,3.5 \mathrm{~Hz}, 1 \mathrm{H}), 2.92(\mathrm{dd}, J=17.7,6.0 \mathrm{~Hz}, 1 \mathrm{H}) ;{ }^{13} \mathrm{C}$ NMR $\left(101 \mathrm{MHz}\right.$, acetone- $\left.d_{6}\right): \delta 176.8,175.8,161.4,138.7,137.7$, 133.0, 128.7, 126.7, 124.0, 123.8, 120.6, 51.8, 37.1; HRMS ESI $(\mathrm{m} / \mathrm{z})$ : $[\mathrm{M}+\mathrm{Na}]^{+}$calcd for $\mathrm{C}_{13} \mathrm{H}_{9} \mathrm{ClN}_{2} \mathrm{O}_{3} \mathrm{SNa}, 303.991201$; found, 303.99146; $[2 \mathrm{M}+\mathrm{Na}]^{+}$calcd for $\mathrm{C}_{26} \mathrm{H}_{18} \mathrm{Cl}_{2} \mathrm{~N}_{4} \mathrm{O}_{6} \mathrm{~S}_{2} \mathrm{Na}^{+}, 638.99425$; found, 638.99370 .

3,4-Dichloro- $N$-(2,5-dioxopyrrolidin-3-yl) benzo[b]thiophene-2carboxamide (7h). Compound $7 \mathrm{~h}$ was synthesized according to the general procedure C using $3 \mathrm{a}(100 \mathrm{mg}, 0.44 \mathrm{mmol})$, DIPEA $(0.15 \mathrm{~mL}$, $0.88 \mathrm{mmol}$ ), and 3,4-dichlorobenzo[ $b]$ thiophene-2-carbonyl chloride 6h (116 mg, $0.44 \mathrm{mmol}$ ). After purification via flash column chromatography ( $n$-hexane/EtOAc, $1: 1 \mathrm{v} / \mathrm{v})$, compound $7 \mathrm{~h}$ (63.6 $\mathrm{mg}, 0.27 \mathrm{mmol}, 62 \%)$ was isolated as a light-yellow solid. TLC ( $n-$ hexane/EtOAc, $3: 7 \mathrm{v} / \mathrm{v}): R_{\mathrm{F}}=0.46 ; \mathrm{mp} 159-162{ }^{\circ} \mathrm{C}$; IR $(\mathrm{KBr}) \tilde{\nu}_{\max }$ : 3396.03, 3192.58, 1135.62, 1620.88, 1532.17, $1193.72 .755 .244 \mathrm{~cm}^{-1}$; ${ }^{1} \mathrm{H}$ NMR (300 MHz, DMSO-d $\left.d_{6}\right): \delta 11.35(\mathrm{~s}, 1 \mathrm{H}), 9.10(\mathrm{~d}, J=7.8 \mathrm{~Hz}$, $1 \mathrm{H}), 8.10(\mathrm{dd}, J=7.9,1.2 \mathrm{~Hz}, 1 \mathrm{H}), 7.62-7.48(\mathrm{~m}, 2 \mathrm{H}), 4.83-4.73(\mathrm{~m}$, $1 \mathrm{H}), 2.99(\mathrm{dd}, J=17.6,9.3 \mathrm{~Hz}, 1 \mathrm{H}), 2.67(\mathrm{dd}, J=17.5,5.6 \mathrm{~Hz}, 1 \mathrm{H}) ;{ }^{13} \mathrm{C}$ NMR (75 MHz, DMSO- $\left.d_{6}\right): \delta 177.1,176.4,160.3,139.6,133.7,130.6$, 128.4, 128.1, 123.1, 118.5, 50.4, 36.1, 30.8; HRMS ESI $(m / z):[\mathrm{M}+$ $\mathrm{Na}]^{+}$calcd for $\mathrm{C}_{13} \mathrm{H}_{8} \mathrm{Cl}_{2} \mathrm{~N}_{2} \mathrm{O}_{3} \mathrm{SNa}^{+}, 364.95304$; found, 364.95249 .

tert-Butyl (4-(((2,5-Dioxopyrrolidin-3-yl)carbamoyl)oxy)methyl)benzyl)carbamate (10a). Compound 10a was synthesized according to the general procedure $\mathrm{D}$. To a $15 \%$ wt solution of $\mathrm{COCl}_{2}$ in toluene $(12.3 \mathrm{~mL}, 17.29 \mathrm{mmol})$, a solution of $8(3.15 \mathrm{~g}, 13.3 \mathrm{mmol})$ in THF was added. After evaporation of the volatiles, compound 9 was produced. By using 3a (2.8 g, $12.4 \mathrm{mmol})$, DIPEA ( $4.0 \mathrm{~mL}, 23.0 \mathrm{mmol})$, and the chloroformate 9 ( $3.6 \mathrm{~g}, 12.0 \mathrm{mmol}$ ), compound 10a was synthesized. After purification via flash column chromatography (DCM/MeOH 0$2 \% \mathrm{v} / \mathrm{v})$, compound $10 \mathrm{a}(4.3 \mathrm{~g}, 11.4 \mathrm{mmol}, 95 \%)$ was isolated as a white solid. TLC $(\mathrm{DCM} / \mathrm{MeOH}, 5: 0.3 \mathrm{v} / \mathrm{v}): R_{\mathrm{f}}=0.81 ; \mathrm{mp} 80-82{ }^{\circ} \mathrm{C}$; IR $(\mathrm{KBr}) \tilde{\nu}_{\max }: 3412,1718,1528,1267,1170 \mathrm{~cm}^{-1}$; ${ }^{1} \mathrm{H}$ NMR: $(300 \mathrm{MHz}$, $\left.\mathrm{CDCl}_{3}\right): \delta 9.32(\mathrm{~s}, 1 \mathrm{H}), 7.21(\mathrm{q}, J=8.0 \mathrm{~Hz}, 4 \mathrm{H}), 6.20(\mathrm{~s}, 1 \mathrm{H}), 5.14(\mathrm{~s}$, $1 \mathrm{H}), 5.02(\mathrm{~s}, 2 \mathrm{H}), 4.24(\mathrm{~s}, 3 \mathrm{H}), 2.90(\mathrm{~d}, J=8.8 \mathrm{~Hz}, 1 \mathrm{H}), 2.71(\mathrm{~d}, J=$ $17.6 \mathrm{~Hz}, 1 \mathrm{H}), 1.43(\mathrm{~s}, 9 \mathrm{H}) ;{ }^{13} \mathrm{C} \mathrm{NMR}\left(100 \mathrm{MHz}, \mathrm{CDCl}_{3}\right): \delta 28.5,36.7$, 44.3, 51.3, 67.3, 79.9, 127.5, 128.6, 134.9, 139.4, 156.3, 175.2, 177.0; HRMS ESI $(m / z):[\mathrm{M}+\mathrm{Na}]^{+}$calcd for $\mathrm{C}_{18} \mathrm{H}_{23} \mathrm{~N}_{3} \mathrm{O}_{6} \mathrm{Na}^{+}$, 400.14850; found, 400.14782 .

tert-Butyl (4-(((2,6-Dioxopiperidin-3-yl)carbamoyl)oxy)methyl)benzyl)carbamate (10b). Compound $10 \mathrm{~b}$ was synthesized according to the general procedure $\mathrm{D}$. To a $15 \%$ wt solution of $\mathrm{COCl}_{2}$ in toluene $(12.3 \mathrm{~mL}, 17.3 \mathrm{mmol})$, a solution of $8(3.15 \mathrm{~g}, 13.3 \mathrm{mmol})$ in THF was added. After evaporation of the volatiles, compound 9 was produced. By using $3 \mathbf{b}(3.0 \mathrm{mg}, 12.4 \mathrm{mmol})$, DIPEA $(4.0 \mathrm{~mL}, 23 \mathrm{mmol})$, and the chloroformate 9 ( $3.6 \mathrm{~g}, 12.0 \mathrm{mmol}$ ) compound $10 \mathrm{~b}$ was synthesized. After purification via flash column chromatography (DCM/MeOH 0$2 \% \mathrm{v} / \mathrm{v})$, compound $10 \mathrm{~b}(4.23 \mathrm{~g}, 10.8 \mathrm{mmol}, 90 \%)$ was isolated as a white solid. TLC $\left(n\right.$-hexane/EtOAc, 3:7 v/v): $R_{\mathrm{F}}=0.16$; mp $154.4^{\circ} \mathrm{C}$; IR (KBr) $\tilde{\nu}_{\max }: 3412.42,3100.01,2977.55,2927.41,2853.17,1698.98$, $1524.45 \mathrm{~cm}^{-1}$; ${ }^{1} \mathrm{H}$ NMR: $\left(300 \mathrm{MHz}, \mathrm{CDCl}_{3}\right): \delta 8.19(\mathrm{~s}, 1 \mathrm{H}), 7.35-$ $7.27(\mathrm{~m}, 4 \mathrm{H}), 5.65(\mathrm{~s}, 1 \mathrm{H}), 5.11(\mathrm{~s}, 2 \mathrm{H}), 4.90(\mathrm{~s}, 1 \mathrm{H}), 4.44-4.20(\mathrm{~m}$, $3 \mathrm{H}), 2.90-2.47(\mathrm{~m}, 3 \mathrm{H}), 1.96-1.83(\mathrm{~m}, 1 \mathrm{H}), 1.45(\mathrm{~s}, 9 \mathrm{H}) ;{ }^{13} \mathrm{C}$ NMR: $\left(75 \mathrm{MHz}, \mathrm{CDCl}_{3}\right): \delta 171.1,171.0,156.1,155.9,139.2,135.0,128.5$, 127.6, 77.2, 67.0, 52.2, 44.4, 31.2, 28.4, 25.3; HRMS ESI $(\mathrm{m} / z)$ : [M + $\mathrm{Na}]^{+}$calcd for $\mathrm{C}_{19} \mathrm{H}_{25} \mathrm{~N}_{3} \mathrm{O}_{6} \mathrm{Na}^{+}$, 414.16410; found, 414.16326.

(4-(((2,5-Dioxopyrrolidin-3-yl)carbamoyl)oxy)methyl)phenyl)methanaminium 2,2,2-Trifluoroacetate (11a). Compound 11a was synthesized according to the general procedure D using 10a (3.8 g, 10 $\mathrm{mmol})$ and TFA $(23 \mathrm{~mL}, 300 \mathrm{mmol})$. Upon completion, the volatiles were completely evaporated to give $11 \mathrm{a}(3.91 \mathrm{~g}, 10 \mathrm{mmol}$, quant $)$ as a white solid. TLC $(\mathrm{DCM} / \mathrm{MeOH}, 5: 2 \mathrm{v} / \mathrm{v}): R_{\mathrm{f}}=0.26 ; \mathrm{mp} 197-200^{\circ} \mathrm{C}$; IR (KBr) $\tilde{\nu}_{\max }: 3450,1780,1719,1526,1203,1180 \mathrm{~cm}^{-1}$; ${ }^{1} \mathrm{H}$ NMR: $\left(400 \mathrm{MHz}, \mathrm{DMSO}-d_{6}\right): \delta 7.47(\mathrm{~s}, 4 \mathrm{H}), 5.15(\mathrm{~s}, 2 \mathrm{H}), 4.46(\mathrm{dd}, J=9.3$, $5.9 \mathrm{~Hz}, 1 \mathrm{H}), 4.13(\mathrm{~s}, 2 \mathrm{H}), 3.02(\mathrm{dd}, J=17.8,9.3 \mathrm{~Hz}, 1 \mathrm{H}), 2.68(\mathrm{dd}, J=$ $17.8,5.9 \mathrm{~Hz}, 1 \mathrm{H}) ;{ }^{13} \mathrm{C}$ NMR (100 MHz, DMSO- $\left.d_{6}\right): \delta 179.5,177.9$, 139.3, 134.2, 130.1, 129.5, 67.2, 52.4, 44.0, 37.3, 27.72; ${ }^{19} \mathrm{~F}$ NMR (282 $\mathrm{MHz}$, DMSO- $\left.d_{6}\right): \delta-73.61$; HRMS ESI $(\mathrm{m} / z):[\mathrm{M}+\mathrm{Na}]^{+}$calcd for $\mathrm{C}_{13} \mathrm{H}_{15} \mathrm{~N}_{3} \mathrm{O}_{4} \mathrm{Na}^{+}$, 278.11353; found, 278.11345.

(4-((((2,6-Dioxopiperidin-3-yl)carbamoyl)oxy)methyl)phenyl)methanaminium 2,2,2-Trifluoroacetate (11b). Compound $11 \mathrm{~b}$ was synthesized according to the general procedure D using $(3.91 \mathrm{~g}, 10$ $\mathrm{mmol})$ and TFA $(23 \mathrm{mg}, 300 \mathrm{mmol})$. Upon completion, the volatiles were completely evaporated to give $11 \mathbf{b}(4.05 \mathrm{~g}, 10 \mathrm{mmol}$, quant) as a white solid. TLC (DCM/MeOH, 5:2 v/v): $R_{\mathrm{F}}=0.3 ; \mathrm{mp} 58-60{ }^{\circ} \mathrm{C}$; IR $(\mathrm{KBr}) \tilde{\nu}_{\max }: 3419.17,3240.79,3094.23,1698.98,1532.17,1251.58$, 1204.33, $1136.83 \mathrm{~cm}^{-1}$; ${ }^{1} \mathrm{H}$ NMR: (300 MHz, DMSO): $\delta 7.54-7.38$ $(\mathrm{m}, 4 \mathrm{H}), 5.24-5.11(\mathrm{~m}, 2 \mathrm{H}), 4.45-4.35(\mathrm{~m}, 1 \mathrm{H}), 4.12(\mathrm{~s}, 2 \mathrm{H}), 2.87-$ $2.61(\mathrm{~m}, 2 \mathrm{H}), 2.24-1.94(\mathrm{~m}, 2 \mathrm{H}) ;{ }^{13} \mathrm{C}$ NMR: (100 MHz, DMSO): $\delta$ 173.4, 172.4, 157.1, 138.1, 132.6, 128.7, 128.0, 65.6, 51.3, 42.6, 30.7, $24.4 ;{ }^{19} \mathrm{~F}$ NMR $\left(282 \mathrm{MHz}\right.$, DMSO- $\left.d_{6}\right): \delta-73.70$; HRMS $(\mathrm{m} / z):[\mathrm{M}+$ $\mathrm{H}]^{+}$calcd for $\mathrm{C}_{14} \mathrm{H}_{18} \mathrm{~N}_{3} \mathrm{O}_{4}{ }^{+}$, 292.12973; found, 292.12885 .

4-((4-(((2,5-Dioxopyrrolidin-3-yl)carbamoyl)oxy)methyl)benzyl)amino)-4-oxobutanoic Acid (12a). Compound 12a was synthesized according to the general procedure $\mathrm{E}$ using $11 \mathrm{a}(175 \mathrm{mg}, 0.45 \mathrm{mmol})$, succinic anhydride $(44.7 \mathrm{mg}, 0.45 \mathrm{mmol})$, and $\mathrm{Et}_{3} \mathrm{~N}(0.14 \mathrm{~mL}, 0.98$ $\mathrm{mmol}$ ). After purification via flash column chromatography, (EtOAc/ $\mathrm{IPA} / \mathrm{H}_{2} \mathrm{O}$ 4:2:1) compound 12a (128 mg, $\left.0.34 \mathrm{mmol}, 76 \%\right)$ was isolated as a white solid. TLC (EtOAc/iPA/ $\mathrm{H}_{2} \mathrm{O}$ 4:3:2 v/v): $R_{\mathrm{f}}=0.45$; $\mathrm{mp} 110^{\circ} \mathrm{C}$; IR $(\mathrm{KBr}) \tilde{\nu}_{\max }: 3747.98,3739.3,2922.59,1649.8,1555.31$, $1539.88,1520.6,1511.92 \mathrm{~cm}^{-1}$; ${ }^{1} \mathrm{H}$ NMR $\left(300 \mathrm{MHz}, \mathrm{DMSO}-d_{6}\right): \delta$ $8.53(\mathrm{t}, J=5.8 \mathrm{~Hz}, 1 \mathrm{H}), 7.86(\mathrm{~d}, J=8.2 \mathrm{~Hz}, 1 \mathrm{H}), 7.25(\mathrm{q}, J=8.1 \mathrm{~Hz}$, $4 \mathrm{H}), 4.99(\mathrm{~s}, 2 \mathrm{H}), 4.42-4.32(\mathrm{~m}, 1 \mathrm{H}), 4.23(\mathrm{~d}, J=5.9 \mathrm{~Hz}, 2 \mathrm{H}), 2.94-$ $2.83(\mathrm{~m}, 1 \mathrm{H}), 2.53-2.43(\mathrm{~m}, 1 \mathrm{H}), 2.37-2.25(\mathrm{~m}, 4 \mathrm{H}) ;{ }^{13} \mathrm{C}$ NMR $(101$ $\left.\mathrm{MHz}, \mathrm{DMSO}-d_{6}\right): \delta 178.1,176.5,176.0,172.6,155.9,139.7,135.2$, 128.1, 127.3, 65.8, 50.7, 41.9, 36.3, 32.1, 32.0; HRMS ESI $(\mathrm{m} / \mathrm{z}):[\mathrm{M}-$ $\mathrm{H}]^{-}$calcd for $\mathrm{C}_{17} \mathrm{H}_{18} \mathrm{~N}_{3} \mathrm{O}_{7}^{-}$, 376.11447; found, 376.11646.

4-((4-)(((2,6-Dioxopiperidin-3-yl)carbamoyl)oxy)methyl)benzyl)amino)-4-oxobutanoic Acid (12b). Compound 12b was synthesized according to the general procedure $\mathrm{E}$ using $11 \mathrm{~b}(121 \mathrm{mg}, 0.3 \mathrm{mmol})$, succinic anhydride $(30.0 \mathrm{mg}, 0.3 \mathrm{mmol})$, and $\mathrm{Et}_{3} \mathrm{~N}(0.092 \mathrm{~mL}, 0.66$ $\mathrm{mmol}$ ). After purification via flash column chromatography, (EtOAc/ IPA/ $\mathrm{H}_{2} \mathrm{O}$ 4:2:1) compound 12a (117 mg, $0.3 \mathrm{mmol}$, quant) was isolated as a white solid. TLC $\left(\mathrm{EtOAc} / \mathrm{iPA} / \mathrm{H}_{2} \mathrm{O}, 4: 3: 2 \mathrm{v} / \mathrm{v}\right): R_{\mathrm{f}}=0.60$; mp $129{ }^{\circ} \mathrm{C}$; IR (KBr) $\tilde{\nu}_{\max }: 3443.28,1712.48,1700.91,1555.31$, 1539.88, 1522.52, $1202.4 \mathrm{~cm}^{-1}$; ${ }^{1} \mathrm{H}$ NMR $\left(400 \mathrm{MHz}\right.$, DMSO- $\left.d_{6}\right): \delta$ $10.80(\mathrm{~s}, 1 \mathrm{H}), 8.49(\mathrm{~s}, 1 \mathrm{H}), 7.59(\mathrm{~d}, J=8.6 \mathrm{~Hz}, 1 \mathrm{H}), 7.38-7.16(\mathrm{~m}$, $4 \mathrm{H}), 5.02(\mathrm{~s}, 2 \mathrm{H}), 4.36-4.17(\mathrm{~m}, 3 \mathrm{H}), 2.73(\mathrm{ddd}, J=18.1,11.8,7.1 \mathrm{~Hz}$, $1 \mathrm{H}), 2.47(\mathrm{~d}, J=3.7 \mathrm{~Hz}, 1 \mathrm{H}), 2.32(\mathrm{dq}, J=12.3,7.2,6.5 \mathrm{~Hz}, 3 \mathrm{H}), 1.95$ (ddt, $J=17.6,13.4,5.2 \mathrm{~Hz}, 2 \mathrm{H}) ;{ }^{13} \mathrm{C}$ NMR: $\left(101 \mathrm{MHz}, \mathrm{DMSO}-d_{6}\right): \delta$ 173.1, 172.5, 172.3, 156.2, 139.5, 135.4, 127.9, 127.3, 65.5, 50.9, 41.9, 
31.9, 31.8, 31.7, 31.0, 24.4; HRMS ESI $(m / z):[\mathrm{M}-\mathrm{H}]^{-}$calcd for $\mathrm{C}_{18} \mathrm{H}_{20} \mathrm{~N}_{3} \mathrm{O}_{7}^{-}$, 390.13013; found, 390.13109 .

$((1 s, 4 s)-4-(($ tert-Butoxycarbonyl)amino)cyclohexyl)methyl (2,5Dioxopyrrolidin-3-yl)carbamate (15a). Compound 15a was synthesized according to the general procedure D. To a $15 \%$ wt solution of $\mathrm{COCl}_{2}$ in toluene $(12.3 \mathrm{~mL}, 17.3 \mathrm{mmol})$, a solution of $13(3.05 \mathrm{~g}, 13.3$ $\mathrm{mmol}$ ), in THF was added. After evaporation of the volatiles, compound 14 was produced. By using $3 \mathrm{a}(2.8 \mathrm{mg}, 12.4 \mathrm{mmol})$, DIPEA ( $4 \mathrm{~mL}, 23 \mathrm{mmol})$, and the chloroformate $14(3.5 \mathrm{~g}, 12 \mathrm{mmol})$, compound 15a was synthesized. After purification via flash column chromatography (DCM/MeOH 0-2\% v/v), compound 15a (3.9 mg, $10.44 \mathrm{mmol}, 87 \%)$ was isolated as a white solid. TLC (DCM/MeOH, $5: 1 \mathrm{v} / \mathrm{v}): R_{\mathrm{f}}=0.71 ; \mathrm{mp} 95-97{ }^{\circ} \mathrm{C}$; IR $(\mathrm{KBr}) \tilde{\nu}_{\max }: 3381,1715,1523$, 1366, 1257, $1172 \mathrm{~cm}^{-1}$; ${ }^{1} \mathrm{H}$ NMR: $\left(400 \mathrm{MHz}, \mathrm{CDCl}_{3}\right): \delta 8.97(\mathrm{~s}, 1 \mathrm{H})$, $5.77(\mathrm{~s}, 1 \mathrm{H}), 4.76(\mathrm{~s}, 1 \mathrm{H}), 4.40(\mathrm{~s}, 1 \mathrm{H}), 4.00(\mathrm{~s}, 2 \mathrm{H}), 3.74(\mathrm{~s}, 1 \mathrm{H}), 3.12$ $(\mathrm{dd}, J=18.8,10.0 \mathrm{~Hz}, 1 \mathrm{H}), 2.88(\mathrm{~d}, J=18.0 \mathrm{~Hz}, 1 \mathrm{H}), 1.82-1.56(\mathrm{~m}$, $6 \mathrm{H}), 1.47(\mathrm{~s}, 9 \mathrm{H}), 1.31(\mathrm{~s}, 2 \mathrm{H}) ;{ }^{13} \mathrm{C} \mathrm{NMR}\left(101 \mathrm{MHz}, \mathrm{CDCl}_{3}\right): \delta 177.0$, 175.2, 156.5, 155.3, 79.2, 69.1, 51.3, 46.3, 36.7, 35.2, 29.2, 28.4, 24.3; HRMS ESI $(m / z):[\mathrm{M}+\mathrm{Na}]^{+}$calcd for $\mathrm{C}_{17} \mathrm{H}_{27} \mathrm{~N}_{3} \mathrm{O}_{6} \mathrm{Na}^{+}, 392.17976$; found, 392.18342 .

((1s,4s)-4-((tert-Butoxycarbonyl)amino)cyclohexyl)methyl (2,6Dioxopiperidin-3-yl)carbamate (15b). Compound 15b was synthesized according to the general procedure $\mathrm{D}$. To a $15 \% \mathrm{wt}$ solution of $\mathrm{COCl}_{2}$ in toluene $(12.3 \mathrm{~mL}, 17.3 \mathrm{mmol})$, a solution of $13(3.05 \mathrm{~g}, 13.3$ $\mathrm{mmol}$ ) in THF was added. After evaporation of the volatiles, compound 14 was produced. By using $3 \mathbf{b}(3.0 \mathrm{mg}, 12.4 \mathrm{mmol})$, DIPEA $(4 \mathrm{~mL}, 23$ $\mathrm{mmol})$, and the chloroformate $14(3.5 \mathrm{mg}, 12 \mathrm{mmol})$, compound $15 \mathrm{~b}$ was synthesized. After purification via flash column chromatography (DCM/MeOH 0-2\% v/v), compound $15 b$ (2.99 g, $7.8 \mathrm{mmol}, 65 \%)$ was isolated as a white solid. TLC $(\mathrm{DCM} / \mathrm{MeOH}, 5: 2 \mathrm{v} / \mathrm{v}): R_{\mathrm{f}}=0.76$; mp 133-137 ${ }^{\circ} \mathrm{C}$; IR (KBr) $\tilde{\nu}_{\max }: 3379,1703,1523,1247,1198,1171$ $\mathrm{cm}^{-1}$; ${ }^{1} \mathrm{H}$ NMR: $\left(400 \mathrm{MHz}, \mathrm{CDCl}_{3}\right): \delta 8.33(\mathrm{~s}, 1 \mathrm{H}), 5.57(\mathrm{~s}, 1 \mathrm{H}), 4.50$ $(\mathrm{d}, J=130.1 \mathrm{~Hz}, 2 \mathrm{H}), 3.85(\mathrm{~d}, J=97.0 \mathrm{~Hz}, 3 \mathrm{H}), 2.91-2.32(\mathrm{~m}, 3 \mathrm{H})$, $1.91-1.13(\mathrm{~m}, 18 \mathrm{H}) ;{ }^{13} \mathrm{C} \mathrm{NMR}\left(101 \mathrm{MHz}, \mathrm{CDCl}_{3}\right): \delta 171.4,171.3$, 156.5, 155.4, 79.5, 69.0, 53.4, 46.4, 35.5, 31.3, 29.3, 28.5, 25.3, 24.3; HRMS ESI $(m / z):[\mathrm{M}+\mathrm{Na}]^{+}$calcd for $\mathrm{C}_{18} \mathrm{H}_{29} \mathrm{~N}_{3} \mathrm{O}_{6} \mathrm{Na}^{+}$, 406.19541; found, 406.19381.

$((1 s, 4 s)-4-(((2,5-D i o x o p y r r o l i d i n-3-y l)$ carbamoyl)oxy)methyl)cyclohexyl)methanaminium 2,2,2-Trifluoroacetate (16a). Compound 16a was synthesized according to the general procedure $\mathrm{D}$ using 15a (3.7 g, $10 \mathrm{mmol})$ and TFA $(23 \mathrm{~mL}, 300 \mathrm{mmol})$. Upon completion, the volatiles were completely evaporated to give $16 \mathrm{a}(3.83$ $\mathrm{g}, 10 \mathrm{mmol}$, quant) as a white solid. TLC (DCM/MeOH, 5:1 v/v): $R_{\mathrm{f}}=$ 0.21 ; mp $74-76{ }^{\circ} \mathrm{C}$; IR (KBr) $\tilde{\nu}_{\max }: 3447,1783,1717,1629,1529$, 1267, 1203, 1182, $1138 \mathrm{~cm}^{-1}$; ${ }^{1} \mathrm{H}$ NMR: (400 MHz, DMSO-d $\left.d_{6}\right): \delta$ $11.23(\mathrm{~s}, 1 \mathrm{H}), 7.90-7.71(\mathrm{~m}, 4 \mathrm{H}), 4.53-4.21(\mathrm{~m}, 1 \mathrm{H}), 3.98-3.86(\mathrm{~m}$, $3 \mathrm{H}), 3.16(\mathrm{~s}, 1 \mathrm{H}), 2.88(\mathrm{dd}, J=17.5,9.4 \mathrm{~Hz}, 1 \mathrm{H}), 2.45(\mathrm{~d}, J=5.7 \mathrm{~Hz}$, $1 \mathrm{H}), 1.87-1.35(\mathrm{~m}, 9 \mathrm{H}) ;{ }^{13} \mathrm{C}$ NMR (75 MHz, DMSO $): \delta 178.3,176.6$, 156.4, 66.6, 50.9, 48.1, 36.6, 33.5, 26.4, 23.6; ${ }^{19} \mathrm{~F}$ NMR $(282 \mathrm{MHz}$, DMSO- $\left.d_{6}\right): \delta-73.69$; HRMS $(m / z):[\mathrm{M}+2 \mathrm{H}]^{+}$calcd for $\mathrm{C}_{12} \mathrm{H}_{20} \mathrm{~N}_{3} \mathrm{O}_{4}^{+}, 270.14483$; found, 270.14076 .

((1s,4s)-4-(((2,6-Dioxopiperidin-3-yl)carbamoyl)oxy)methyl)cyclohexyl)methanaminium 2,2,2-Trifluoroacetate (16b). Compound $16 \mathrm{~b}$ was synthesized according to the general procedure $\mathrm{D}$ using 15b (3.8 g, $10 \mathrm{mmol})$ and TFA $(23 \mathrm{~mL}, 300 \mathrm{mmol})$. Upon completion, the volatiles were completely evaporated to give $16 \mathbf{b}(3.97$ g, $10.0 \mathrm{mmol}$, quant) as a white solid. TLC (DCM/MeOH, 5:1 v/v): $R_{\mathrm{F}}$ $=0.20$; mp 189-191 ${ }^{\circ} \mathrm{C}$; IR (KBr) $\tilde{\nu}_{\max }: 3454,1747,1724,1677,1622$, 1546, 1248, 1201, 1188, $1137 \mathrm{~cm}^{-1}$; ${ }^{1} \mathrm{H}$ NMR: (400 MHz, DMSO-d 6 ): $\delta 10.78(\mathrm{~s}, 1 \mathrm{H}), 7.80(\mathrm{~s}, 3 \mathrm{H}), 7.44(\mathrm{~s}, 1 \mathrm{H}), 4.28(\mathrm{~s}, 1 \mathrm{H}), 3.94(\mathrm{dd}, J=$ $16.4,5.5 \mathrm{~Hz}, 3 \mathrm{H}), 3.19(\mathrm{~s}, 1 \mathrm{H}), 2.73(\mathrm{~s}, 1 \mathrm{H}), 2.00-1.40(\mathrm{~m}, 11 \mathrm{H}) ;{ }^{13} \mathrm{C}$ NMR (101 MHz, DMSO): 173.4, 172.9, 156.8, 66.4, 51.2, 48.2, 33.6, 31.4, 26.4, 24.8, 23.6; ${ }^{19} \mathrm{~F}$ NMR (282 MHz, DMSO- $\left.d_{6}\right): \delta-73.96$; HRMS $(m / z):[\mathrm{M}+2 \mathrm{H}]^{+}$calcd for $\mathrm{C}_{13} \mathrm{H}_{22} \mathrm{~N}_{3} \mathrm{O}_{4}{ }^{+}, 284.16048$; found, 284.15961.

tert-Butyl (2S)-2-(((2,6-Dioxopiperidin-3-yl)carbamoyl)oxy)methyl)pyrrolidine-1-carboxylate (19b). Compound $19 b$ was synthesized according to the general procedure $\mathrm{D}$. To a $15 \%$ wt solution of $\mathrm{COCl}_{2}$ in toluene $(12.3 \mathrm{~mL}, 17.3 \mathrm{mmol})$, a solution of $17(2.68 \mathrm{~g}, 13.3$ $\mathrm{mmol}$ ) in THF was added. After evaporation of the volatiles, compound
18 was produced. By using $3 \mathbf{b}(3.0 \mathrm{~g}, 12.4 \mathrm{mmol})$, DIPEA ( $4 \mathrm{~mL}, 23$ $\mathrm{mmol})$, and the chloroformate $18(3.16 \mathrm{~g}, 12 \mathrm{mmol})$, compound $\mathbf{1 9 b}$ was synthesized. After purification via flash column chromatography (DCM/MeOH 0-2\% v/v), compound $19 \mathrm{~b}(3.07 \mathrm{~g}, 8.64 \mathrm{mmol}, 72 \%)$ was isolated as a white solid. TLC (DCM/MeOH, 5:0.5 v/v): $R_{\mathrm{f}}=0.42$; mp 81-83 ${ }^{\circ} \mathrm{C}$; IR (KBr) $\tilde{\nu}_{\max }: 3437,1698,1540,1403,1249,1201$, $1171 \mathrm{~cm}^{-1}$; ${ }^{1} \mathrm{H}$ NMR: $\left(400 \mathrm{MHz}, \mathrm{CDCl}_{3}\right): \delta 8.30(\mathrm{~s}, 1 \mathrm{H}), 5.59(\mathrm{~s}, 1 \mathrm{H})$, $4.46-3.82(\mathrm{~m}, 4 \mathrm{H}), 3.52-3.10(\mathrm{~m}, 2 \mathrm{H}), 2.94-2.33(\mathrm{~m}, 3 \mathrm{H}), 2.03-$ $1.77(\mathrm{~m}, 5 \mathrm{H}), 1.46(\mathrm{~s}, 9 \mathrm{H}) ;{ }^{13} \mathrm{C} \mathrm{NMR}\left(101 \mathrm{MHz}, \mathrm{CDCl}_{3}\right): \delta 171.2$, 156.1, 154.5, 65.7, 55.7, 52.2, 46.7, 46.5, 31.2, 28.5, 27.8, 25.3, 23.7, 22.9; HRMS ESI $(m / z):[\mathrm{M}+\mathrm{Na}]^{+}$calcd for $\mathrm{C}_{16} \mathrm{H}_{25} \mathrm{~N}_{3} \mathrm{O}_{6} \mathrm{Na}^{+}$, 378.16411; found, 378.16862 .

(2S)-2-(((2,6-Dioxopiperidin-3-yl) carbamoyl)oxy)methyl)pyrrolidin-1-ium 2,2,2-Trifluoroacetate (20b). Compound 20b was synthesized according to the general procedure $\mathrm{D}$ using $19 \mathrm{~b}$ ( $3.55 \mathrm{~g}, 10$ $\mathrm{mmol})$ and TFA $(23 \mathrm{~mL}, 300 \mathrm{mmol})$. Upon completion, the volatiles were completely evaporated to give $20 \mathrm{~b}(3.69 \mathrm{~g}, 10 \mathrm{mmol}$, quant $)$ as a white solid. TLC (DCM/MeOH, 5:0.5 v/v): $R_{\mathrm{F}}=0.19 ; \mathrm{mp} 149-151$ ${ }^{\circ} \mathrm{C}$; IR (KBr) $\tilde{\nu}_{\max }: 3479,1705,1541,1253,1204,1135 \mathrm{~cm}^{-1}$; ${ }^{1} \mathrm{H}$ NMR: (400 MHz, DMSO): $\delta 10.82(\mathrm{~s}, 1 \mathrm{H}), 9.24(\mathrm{~s}, 1 \mathrm{H}), 8.74(\mathrm{~s}, 1 \mathrm{H}), 7.62$ $(\mathrm{d}, J=8.5 \mathrm{~Hz}, 1 \mathrm{H}), 4.48-4.04(\mathrm{~m}, 3 \mathrm{H}), 3.76(\mathrm{~s}, 1 \mathrm{H}), 3.19(\mathrm{~s}, 2 \mathrm{H}), 2.74$ (ddd, $J=18.2,12.7,6.1 \mathrm{~Hz}, 1 \mathrm{H}), 2.12-1.81(\mathrm{~m}, 5 \mathrm{H}), 1.79-1.57(\mathrm{~m}$, $1 \mathrm{H}) ;{ }^{13} \mathrm{C}$ NMR (101 MHz, DMSO): $\delta 173.4,172.7,156.0,63.8,58.2$, $51.3,45.8,31.4,26.9,24.7,23.7 ;{ }^{19} \mathrm{~F}$ NMR (282 MHz, DMSO- $\left.d_{6}\right): \delta$ -74.36; HRMS $(\mathrm{m} / z):[\mathrm{M}+\mathrm{H}]^{+}$calcd for $\mathrm{C}_{11} \mathrm{H}_{18} \mathrm{~N}_{3} \mathrm{O}_{4}{ }^{+}, 256.12918$; found, 256.12905 .

Cloning, Expression and Protein Purification. WT MsCI4 was cloned, expressed, and purified as previously described. ${ }^{56}$ In an additional construct (humanized MsCI4), surface exposed residues were mutated to mimic hCRBN. The gene carrying the mutations A52H, M54Y, F56H, R68N, A72R, I87V, and L89Q was codon optimized for expression in E. coli and synthesized (eurofins). Humanized MsCI4 was cloned via BamHI and XhoI restriction sites into pETHis_1a; expression and purification were performed as described for $\overline{\mathrm{W}} \mathrm{T}$ MsCI4.

FRET Assay. FRET-based binding assay was performed using WT $\mathrm{MsCI} 4$ as described previously. ${ }^{56}$ Compounds were dissolved in DMSO with the exception of $11 \mathbf{a} / \mathbf{b}, 16 a / b$, and $20 a / b$, which were water-soluble, and compounds $12 \mathbf{a} / \mathbf{b}$ that were dissolved in bicarbonate buffer. Because of remaining impurities, 20a was not tested in this assay and only used for structural studies. For compounds $4 a, 4 c, 5 a, 7 a, 7 b, 7 e$, and $7 g$, binding was observed but could not be quantified, as saturation at higher concentrations was not appreciable in their binding curves. $K_{\mathrm{i}}$ values are summarized in Table S1.

Crystallography. For crystallization, MsCI4 and humanized MsCI4 protein solution were concentrated to $17 \mathrm{mg} / \mathrm{mL}$ and mixed with either $3 \mathrm{mM}$ thalidomide (MsCI4 and humanized MsCI4) or $7 \mathbf{d}$ (MsCI4). Crystallization trials for humanized MsCI4-thalidomide, which turned out to be humanized MsCI4.CBG, and MsCI4.7 d were performed via the vapor diffusion technique at $294 \mathrm{~K}$ in sitting-drops. $400 \mathrm{~nL}$ of protein solution was mixed with $400 \mathrm{~nL}$ of reservoir solution with the Honeybee 963 robot (Genomic Solutions Ltd.). Diffraction-quality crystals of humanized MsCI4.CBG were obtained in a condition containing 20\% PEG 3350 and $0.2 \mathrm{M}$ ammonium acetate, and crystals of MsCI4.7d were obtained using $15 \%$ PEG $6 \mathrm{~K}$ and $5 \%$ glycerol. For all other compounds, crystals were prepared in hanging drop experiments by mixing $1 \mu \mathrm{L} 0.4 \mathrm{M}\left(\mathrm{NH}_{4}\right)_{2} \mathrm{HPO}_{4}$ ground solution with $1 \mu \mathrm{L} \mathrm{MsCI} 4$. thalidomide solution. Crystals grown in this setup were transferred to 3 $\mu \mathrm{L}$ ground solution spiked with individual compounds for soaking. After $36 \mathrm{~h}$, crystals were cryoprotected by streaking through a 50\% PEG 3350 solution. Crystals were flash-cooled in liquid nitrogen, and diffraction data were collected at $100 \mathrm{~K}$ and a wavelength of $1 \AA$ on beamline X10SA at the Swiss Light Source using a PILATUS 6M-F hybrid pixel detector (Dectris Ltd.). Data were processed and scaled using XDS. ${ }^{57}$ Structures of soaking experiments were solved based on the MsCI4.thalidomide coordinates (PDB 4v2y). The cocrystal structures of the complexes with $\mathrm{CBG}$ and $\mathbf{7 d}$ were of other crystal forms and were solved using molrep ${ }^{58}$ with $4 \mathrm{v} 2 \mathrm{y}$ as a search model, locating four and two chains in the ASU, respectively. All structures were rebuilt using $\operatorname{Coot}^{59}$ and the integrated suite Lidia for chemical 
Table 1. Data Collection and Refinement Statistics

\begin{tabular}{|c|c|c|c|c|c|c|c|c|c|c|}
\hline & $\mathrm{MsCI} 4 \cdot 4 \mathrm{a}$ & $\mathrm{MsCI} 4 \cdot 4 \mathrm{~b}$ & $\mathrm{MsCI} 4 \cdot 5 \mathrm{a}$ & $\mathrm{MsCI} 4 \cdot 5 \mathrm{~b}$ & $\mathrm{MsCI} 4 \cdot 7 \mathrm{a}$ & \multicolumn{2}{|c|}{$\mathrm{MsCI} 4 \cdot 7 \mathrm{~b}$} & $\mathrm{MsCI} 4 \cdot 7 \mathrm{c}$ & $\mathrm{MsCI} 4 \cdot 7 \mathrm{~d}$ & $\mathrm{MsCI} 4 \cdot 7 \mathrm{f}$ \\
\hline \multicolumn{11}{|c|}{ Data Collection } \\
\hline space group & $P 2_{1} 2_{1} 2_{1}$ & $P 2_{1} 2_{1} 2_{1}$ & $P 2_{1} 2_{1} 2_{1}$ & $P 2_{1} 2_{1} 2_{1} \quad P$ & $P 2_{1} 2_{1} 2_{1}$ & \multicolumn{2}{|l|}{$P 2_{1} 2_{1} 2_{1}$} & $P 2_{1} 2_{1} 2_{1}$ & $P 2_{1}$ & $P 2_{1} 2_{1} 2_{1}$ \\
\hline \multicolumn{11}{|c|}{ Unit Cell } \\
\hline$a, b, c(\AA)$ & $\begin{array}{l}56.46,58.82 \\
88.23\end{array}$ & $\begin{array}{l}56.75,58.82 \\
88.57\end{array}$ & $\begin{array}{l}56.95,59.58 \\
89.05\end{array}$ & $\begin{array}{l}56.66,58.71, \\
88.01\end{array}$ & $\begin{array}{l}56.33,58.68 \\
\quad 89.27\end{array}$ & \multicolumn{2}{|c|}{$\begin{array}{l}56.42,58.80 \\
\quad 88.23\end{array}$} & $\begin{array}{l}56.33,58.68 \\
89.27\end{array}$ & $\begin{array}{l}31.63,52.39 \\
59.29\end{array}$ & $\begin{array}{l}56.87,58.55 \\
88.28\end{array}$ \\
\hline$\alpha, \beta, \gamma(\mathrm{deg})$ & $90,90,90$ & $90,90,90$ & $90,90,90$ & $90,90,90$ & $90,90,90$ & \multicolumn{2}{|c|}{$90,90,90$} & $90,90,90$ & $\begin{array}{l}90.0,95.8 \\
90.0\end{array}$ & $90,90,90$ \\
\hline resolution range, $\AA$ & $\begin{array}{l}44.1-1.55 \\
\quad(1.64-1.55)\end{array}$ & $\begin{array}{l}44.28-1.6 \\
\quad(1.7-1.6)\end{array}$ & $\begin{array}{l}44.53-1.7 \\
\quad(1.8-1.7)\end{array}$ & $\begin{array}{l}47.64-1.75 \\
\quad(1.85-1.75)\end{array}$ & $\begin{array}{l}49.03-1.8 \\
\quad(1.86-1.8)\end{array}$ & $\begin{array}{c}48.93-1 \\
(1.84-\end{array}$ & $\begin{array}{l}73 \\
1.73)\end{array}$ & $\begin{array}{l}49.03-1.85 \\
\quad(1.96-1.85)\end{array}$ & $\begin{array}{l}39.2-1.1 \\
\quad(1.16- \\
1.1)\end{array}$ & $\begin{array}{l}44.14-1.65 \\
\quad(1.75-1.65)\end{array}$ \\
\hline redundancy & $12.7(11.8)$ & $12.9(12.9$ & $12.4(12.8)$ & $12.8(12.8)$ & $12.86(12)$ & $12.5(12$ & & $12.9(13.0)$ & $6.3(5.3)$ & $12.9(13.2)$ \\
\hline completeness \% & $99.8(98.9)$ & $99.9(99.4$ & $99.0(98.2)$ & $99.6(97.7)$ & $99.6(97.6)$ & $98.8(92$ & & $99.8(98.6)$ & $99.1(95.1)$ & $99.9(99.6)$ \\
\hline$R$ merge $\%$ & $9.0(98.2)$ & $5.3(82.8)$ & $7.3(94.6)$ & $6.6(98.5)$ & $7.2(89.0)$ & $14.2(88$ & & $6.1(102.8)$ & $5.3(39.4)$ & $6.9(81.5)$ \\
\hline$C C(1 / 2)$ & $99.9(85.4)$ & $100(90.4)$ & $99.9(87.8)$ & $100(87.6)$ & $100(84.6)$ & $99.6(85$ & & $99.9(78.1)$ & $99.8(92.4)$ & $99.9(86.6)$ \\
\hline$I / s(I)$ & $15.09(1.78)$ & $15.09(1.7$ & $20.22(2.02)$ & $20.47(2.27)$ & $22.12(2.39)$ & $10.55(1$ & 73) & $21.46(2.25)$ & $17.67(3.64)$ & $20.72(2.35)$ \\
\hline & & & & Refinemen & & & & & & \\
\hline $\begin{array}{l}\text { number of } \\
\text { reflections (total/ } \\
\text { test) }\end{array}$ & $43370(4254)$ & $\begin{array}{l}39841 \\
\quad(3904)\end{array}$ & $\begin{array}{l}33803 \\
\quad(3354)\end{array}$ & $30301(2985)$ & $\begin{array}{l}28122 \\
\quad(2771)\end{array}$ & 30582( & 2948) & $28122(2771)$ & $\begin{array}{l}77822 \\
\quad(7458)\end{array}$ & $36182(3558)$ \\
\hline no. of atoms & 2871 & 2787 & 2767 & 2709 & 2544 & 2778 & & 2675 & 2082 & 2464 \\
\hline protein & 2572 & 2519 & 2504 & 2523 & 2338 & 2521 & & 2468 & 1768 & 2229 \\
\hline solvent & 223 & 173 & 185 & 134 & 175 & 187 & & 123 & 276 & 166 \\
\hline ligand & 76 & 95 & 78 & 52 & 31 & 70 & & 84 & 38 & 69 \\
\hline$R$ work $\%$ & 0.17 & 0.19 & 0.18 & 0.19 & 0.17 & 0.17 & & 0.18 & 0.12 & 0.20 \\
\hline$R$ free $\%$ & 0.20 & 0.22 & 0.23 & $0.23 \quad 0$ & 0.22 & 0.23 & & 0.22 & 0.15 & 0.22 \\
\hline & & & & Ligand in $\mathrm{Ch}$ & hain & & & & & \\
\hline A & thalidomide & $\begin{array}{l}\text { hydrolyzec } \\
\text { 4b }\end{array}$ & thalidomide & $5 b$ & $7 \mathbf{a}$ & thalidom & & $7 \mathrm{c}$ & & thalidomide \\
\hline B & $4 a$ & $\begin{array}{l}\text { hydrolyzec } \\
\mathbf{4 b}\end{array}$ & hydrolyzed 5a & $5 \mathbf{b}$ & $7 \mathbf{a}$ & $7 \mathbf{b}$ & & $7 \mathrm{c}$ & $\begin{array}{r}\text { co-crystal } \\
\text { with } 7 \mathrm{~d}\end{array}$ & $7 \mathrm{f}$ \\
\hline $\mathrm{C}$ & hydrolyzed 4a & $\begin{array}{l}\text { hydrolyzec } \\
\mathbf{4 b}\end{array}$ & $5 a$ & & & thalidom & & $7 \mathrm{c}$ & & \\
\hline PDB ID & 6R0S & 6R0V & 6R0U & $6 \mathrm{R} 11$ & $6 \mathrm{R} 1 \mathrm{X}$ & $6 \mathrm{R} 12$ & & $6 \mathrm{R} 1 \mathrm{~K}$ & $6 \mathrm{R} 1 \mathrm{D}$ & $6 \mathrm{R} 13$ \\
\hline & $\mathrm{MsCI}$ & $4 \cdot 11 \mathrm{a}$ & $\mathrm{MsCI} 4 \cdot 12 \mathrm{a}$ & $\mathrm{MsCI} 4 \cdot 16 \mathrm{~b}$ & $\mathrm{MsCI}$ & $20 \mathrm{a}$ & & IsCI $4 \cdot 20 b$ & $\mathrm{MsCI} 4 \cdot \mathrm{CBG}$ & \\
\hline & & & & Data Collection & & & & & & \\
\hline space group & $P 2_{1} 2_{1} 2_{1}$ & & $P 2_{1} 2_{1} 2_{1}$ & $\begin{array}{l}P 2_{1} 2_{1} 2_{1} \\
\text { Unit Cell }\end{array}$ & $P 2_{1} 2_{1} 2_{1}$ & & $P 2_{1} 2_{1}$ & & $P 2_{1}$ & \\
\hline$a, b, c(\AA)$ & $56.63,59$. & $59,88.90$ & $56.66,59.02,88.59$ & $56.53,59.44,88.36$ & $56.56,59$ & $3,88.43$ & 56.56 & $59.3,88.0$ & $61.7,59.1,61.7$ & \\
\hline$\alpha, \beta, \gamma(\mathrm{deg})$ & $90,90,90$ & & $90,90,90$ & $90,90,90$ & $90,90,90$ & & 90,90 &, 90 & $90,105.6,90$ & \\
\hline resolution range, $\AA$ & $\begin{array}{l}44.45-1.3 \\
1.35)\end{array}$ & $5(1.43-$ & $\begin{array}{l}49.12-1.5(1.59- \\
1.5)\end{array}$ & $\begin{array}{l}47.62-1.35(1.43- \\
1.35)\end{array}$ & $\begin{array}{l}49.21-1.4 \\
1.45)\end{array}$ & $(1.50-$ & $\begin{array}{c}49.18 \\
1.5\end{array}$ & $-1.54(1.64-$ & $\begin{array}{l}49.17-1.50(1.59- \\
1.50)\end{array}$ & \\
\hline redundancy & $12.7(12.4$ & & $12.6(12.6)$ & $12.6(12.7)$ & $12.8(12.9$ & & 12.6 & 12.1) & $3.4(3.1)$ & \\
\hline completeness \% & $99.9(99.3$ & & $99.5(97.2)$ & $99.8(99.1)$ & $99.8(98.5$ & & 99.5( & 96.7) & $99.0(97.5)$ & \\
\hline$R$ merge $\%$ & $7.4(96.3)$ & & $11.4(78.6)$ & $7.9(98.8)$ & $9.5(89.4)$ & & 13.1 & $81.5)$ & $8.0(88.0)$ & \\
\hline$C C(1 / 2)$ & $99.9(83.2$ & & $99.8(86.5)$ & $99.9(84.0)$ & $99.8(86.2$ & & 99.7( & $83.8)$ & $99.7(83.8)$ & \\
\hline$I / s(I)$ & $17.62(1.9$ & & $14.29(2.32)$ & $16.63(1.85)$ & $14.83(2.1$ & & 10.28 & $(1.71)$ & $9.70(1.15)$ & \\
\hline & & & & Refinement & & & & & & \\
\hline $\begin{array}{l}\text { number of reflections } \\
\text { (total/test) }\end{array}$ & $66738(6$ & 544) & $48282(4739)$ & $66083(6516)$ & $53344(5$ & & 4402 & $6(4112)$ & 68399 (6707) & \\
\hline no. of atoms & 2977 & & 2995 & 3057 & 3074 & & 2928 & & 3985 & \\
\hline protein & 2619 & & 2665 & 2638 & 2634 & & 2617 & & 3480 & \\
\hline solvent & 281 & & 252 & 338 & 339 & & 232 & & 421 & \\
\hline ligand & 77 & & 78 & 81 & 101 & & 79 & & 84 & \\
\hline$R$ work \% & 0.16 & & 0.21 & 0.16 & 0.17 & & 0.18 & & 0.16 & \\
\hline$R$ free $\%$ & 0.19 & & 0.24 & 0.20 & 0.20 & & 0.21 & & 0.20 & \\
\hline & & & & Ligand in Chain & & & & & & \\
\hline A & thalidomi & & thalidomide & thalidomide & thalidomic & & thalid & omide & & \\
\hline B & $10 a$ & & $12 \mathrm{a}$ & $16 b$ & $20 a$ & & thalid & omide & co-crystal with $\mathrm{CBC}$ & \\
\hline $\mathrm{C}$ & thalidomi & & thalidomide & $16 \mathrm{~b}$ & thalidomic & & $20 \mathrm{~b}$ & & & \\
\hline PDB ID & $6 \mathrm{R} 18$ & & $6 \mathrm{R} 1 \mathrm{C}$ & $6 \mathrm{R} 1 \mathrm{~W}$ & 6R19 & & 6R1A & & 6R0Q & \\
\hline
\end{tabular}

structures and generation of restraints. The models were finalized via cyclic modeling in Coot and refinement using REFMAC5. Molecular figures were generated using PyMOL. ${ }^{60}$ Data collection and refinement statistics are summarized in Table 1.
Cell Culture and Western Blot. OPM-2 cells were routinely cultivated in 90\% RPMI $1640+10 \%$ FBS and $1 \%$ penicillin/ streptomycin. Cells were split to $0.3 \times 10^{6}$ cells $/ \mathrm{mL} 2$ days prior to experiments. $4 \mathrm{~mL}$ of culture per well was pipetted in a sterile 
environment. Stock solutions of lenalidomide were prepared at concentrations of 80 and $400 \mathrm{mM}$ and stock solutions of test compounds were prepared at a concentration of $400 \mathrm{mM}$. For the assay, $10 \mu \mathrm{L}$ of stock solutions was added to the $4 \mathrm{~mL}$ cell culture. DMSO controls were prepared in the same manner, leading to a final DMSO concentration of $0.25 \%$. After $24 \mathrm{~h}$ of incubation, cell solution was centrifugated at $500 \mathrm{~g}$. After one washing step with ice cold PBS, cell pellets were resuspended in $35 \mu \mathrm{L}$ of lysis buffer $(20 \mathrm{mM}$ Hepes, 175 $\mathrm{mM} \mathrm{NaCl}, 1 \% \mathrm{NP} 40,2 \mathrm{mM} \mathrm{MgCl} 2$ ) on ice and supplemented with 0.5 $\mu \mathrm{L}$ Benzonase. Samples were resolved by Mini-PROTEAN TGX gels (Bio-Rad) and activated under UV light, before transfer to lowfluorescence PVDF membranes, according to manufacturer's protocol. Membranes were imaged before blocking in 5\% milk in PBS-T and incubating with primary antibodies anti-IKZF3 (15103S, Cell Signaling Technology, Inc.) and anti-CK1 $\alpha$ (ab108296, Abcam plc). After overnight incubation, horseradish peroxidase conjugated secondary antibodies goat anti-rabbit (111-035-144, Jackson Immuno Research) and goat anti-mouse (115-035-003, Jackson Immuno Research) were used at 1:20 000 dilutions for detection of bands by chemiluminescence (ECL Vilbert). Protein bands were detected and integrated using the Bio-Rad analysis suite. Endogenous protein levels were normalized using Stain-Free Technology (Figure S2) and analyzed by one-way ANOVA, according to the Holm-Sidak method integrated into SigmaPlot. The linearity of anti-IKZF3 mAb was tested via serial dilutions of cell extracts (Figure S3).

\section{ASSOCIATED CONTENT}

\section{S Supporting Information}

The Supporting Information is available free of charge on the ACS Publications website at DOI: 10.1021/acs.jmedchem.9b00454.

HPLC traces of tested compounds, western blot quantification and normalization IKZF3, concentration response curve for IKZF3 $\mathrm{mAb}$, and $K_{\mathrm{i}}$ values of tested compounds (PDF)

Molecular formula strings (CSV)

\section{Accession Codes}

Crystal structures have been deposited in the protein data bank (PDB) under the accession codes 6R0S (4a), 6R0V (4b), 6R0U (5a), 6R11 (5b), 6R1X (7a), 6R12 (7b), 6R1K (7c), 6R1D (7d), 6R13 (7f), 6R18 (11a), 6R1C (12a), 6R1W (16b), 6R19 (20a), and 6R1A (20b), 6R0Q (CBG). The authors will release the atomic coordinates and experimental data upon article publication.

\section{AUTHOR INFORMATION}

\section{Corresponding Authors}

*E-mail: giannis@uni-leipzig.de (A.G.).

*E-mail: marcus.hartmann@tuebingen.mpg.de (M.D.H.).

\section{ORCID}

Athanassios Giannis: 0000-0003-2203-0959

Marcus D. Hartmann: 0000-0001-6937-5677

\section{Notes}

The authors declare no competing financial interest.

\section{ACKNOWLEDGMENTS}

We thank Andrei Lupas for continuing support, Reinhard Albrecht for assistance with crystallization and crystallographic data collection, and the staff of beamline X10SA of the Swiss Light Source (PSI, Villigen, Switzerland) for excellent technical support. This work was supported by institutional funds of the Max Planck Society.

\section{ABBREVIATIONS}

4-DMAP, 4-dimethylaminopyridine; AML, acute myeloid leukemia; APP, amyloid precursor protein; ASU, asymmetric unit; BET, bromodomain and extraterminal domain; CBG, $\alpha$ (2-carboxybenzamido)glutarimide; CDI, N,N-carbodiimidazole; CK $1 \alpha$, casein kinase $1 \alpha$; CRBN, cereblon; CRL4 ${ }^{\mathrm{CRBN}}$, CUL4-RBX1-DDB1-CRBN; DIPEA, N,N-diisopropylethylamine; $\mathrm{Et}_{3} \mathrm{~N}$, triethylamine; EtOAc, ethyl acetate; FBS, fetal bovine serum; GSPT1, eukaryotic peptide chain release factor GTP-binding subunit ERF3A; IKZF1, IKAROS family zinc finger 1; IKZF3, zinc finger protein Aiolos; IMiD, immunomodulatory drug; MDS, myelodysplastic syndrome; MM, multiple myeloma; MsCI4, CRBN homologue from magnetospirillum gryphiswaldense; PROTAC, proteolysis targeting chimera; SALL4, sal-like protein 4; VHL, von-Hippel-Lindau

\section{REFERENCES}

(1) Somers, G. F. Pharmacological properties of thalidomide (alphaphthalimido glutarimide), a new sedative hypnotic drug. Br. J. Pharmacol. Chemother. 1960, 15, 111-116.

(2) Lenz, W. A short history of thalidomide embryopathy. Teratology 1988, 38, 203-215.

(3) Vargesson, N. Thalidomide-induced limb defects: resolving a 50year-old puzzle. Bioessays 2009, 31, 1327-1336.

(4) Johnston, R. E.; Abdalla, S. H. Thalidomide in low doses is effective for the treatment of resistant or relapsed multiple myeloma and for plasma cell leukaemia. Leuk. Lymphoma 2002, 43, 351-354.

(5) US Thalomid Label. https://www.accessdata.fda.gov/ drugsatfda_docs/label/2017/020785s061lbl.pdf (accessed Dec 9, 2018).

(6) Bertolini, F.; Mingrone, W.; Alietti, A.; Ferrucci, P. F.; Cocorocchio, E.; Peccatori, F.; Cineri, S.; Mancuso, P.; Corsini, C.; Burlini, A.; Zucca, E.; Martinelli, G. Thalidomide in multiple myeloma, myelodysplastic syndromes and histiocytosis. Analysis of clinical results and of surrogate angiogenesis markers. Ann. Oncol. 2001, 12, 987-990.

(7) Kale, V.; List, A. Immunomodulatory drugs (IMiDs): a new treatment option for myelodysplastic syndromes. Curr. Pharm. Biotechnol. 2006, 7, 339-342.

(8) Wu, H.; Zhao, C.; Gu, K.; Jiao, Y.; Hao, J.; Sun, G. Thalidomide plus chemotherapy exhibit enhanced efficacy in the clinical treatment of T-cell non-Hodgkin's lymphoma: A prospective study of 46 cases. Mol. Clin. Oncol. 2014, 2, 695-700.

(9) García-Sanz, R.; González-López, T. J.; Vázquez, L.; Hermida, G.; Graciani, I. F.; San Miguel, J. F. The combination of thalidomide, cyclophosphamide and dexamethasone is potentially useful in highly resistant Hodgkin's lymphoma. Eur. J. Haematol. 2010, 84, 266-270.

(10) Kuruvilla, J.; Song, K.; Mollee, P.; Panzarella, T.; McCrae, J.; Nagy, T.; Crump, M.; Keating, A. A phase II study of thalidomide and vinblastine for palliative patients with Hodgkin's lymphoma. Hematology 2006, 11, 25-29.

(11) Seldin, D. C.; Choufani, E. B.; Dember, L. M.; Wiesman, J. F.; Berk, J. L.; Falk, R. H.; O’Hara, C.; Fennessey, S.; Finn, K. T.; Wright, D. G.; Skinner, M.; Sanchorawala, V. Tolerability and efficacy of thalidomide for the treatment of patients with light chain-associated (AL) amyloidosis. Clin. Lymphoma 2003, 3, 241-246.

(12) Baird, R.; van Zyl-Smit, R. N.; Iveson, A.; Duddy, J.; Rassam, S. $\mathrm{M}$. Thalidomide is highly effective in a patient with meningeal acute myeloid leukaemia. Leuk. Lymphoma 2004, 45, 179-181.

(13) Thomas, D. A.; Estey, E.; Giles, F. J.; Faderl, S.; Cortes, J.; Keating, M.; O’Brien, S.; Albitar, M.; Kantarjian, H. Single agent thalidomide in patients with relapsed or refractory acute myeloid leukaemia. Br. J. Haematol. 2003, 123, 436-441.

(14) Hartmann, M. D.; Boichenko, I.; Coles, M.; Zanini, F.; Lupas, A. N.; Hernandez Alvarez, B. Thalidomide mimics uridine binding to an aromatic cage in cereblon. J. Struct. Biol. 2014, 188, 225-232. 
(15) Hartmann, M. D.; Boichenko, I.; Coles, M.; Lupas, A. N.; Hernandez Alvarez, B. Structural dynamics of the cereblon ligand binding domain. PLoS One 2015, 10, No. e0128342.

(16) Chamberlain, P. P.; Lopez-Girona, A.; Miller, K.; Carmel, G.; Pagarigan, B.; Chie-Leon, B.; Rychak, E.; Corral, L. G.; Ren, Y. J.; Wang, M.; Riley, M.; Delker, S. L.; Ito, T.; Ando, H.; Mori, T.; Hirano, Y.; Handa, H.; Hakoshima, T.; Daniel, T. O.; Cathers, B. E. Structure of the human cereblon-DDB1-lenalidomide complex reveals basis for responsiveness to thalidomide analogs. Nat. Struct. Mol. Biol. 2014, 21, 803-809.

(17) Fischer, E. S.; Böhm, K.; Lydeard, J. R.; Yang, H.; Stadler, M. B.; Cavadini, S.; Nagel, J.; Serluca, F.; Acker, V.; Lingaraju, G. M.; Tichkule, R. B.; Schebesta, M.; Forrester, W. C.; Schirle, M.; Hassiepen, U.; Ottl, J.; Hild, M.; Beckwith, R. E. J.; Harper, J. W.; Jenkins, J. L.; Thomä, N. $\mathrm{H}$. Structure of the DDB1-CRBN E3 ubiquitin ligase in complex with thalidomide. Nature 2014, 512, 49-53.

(18) Nguyen, T. V.; Lee, J. E.; Sweredoski, M. J.; Yang, S. J.; Jeon, S. J.; Harrison, J. S.; Yim, J. H.; Lee, S. G.; Handa, H.; Kuhlman, B.; Jeong, J. S.; Reitsma, J. M.; Park, C. S.; Hess, S.; Deshaies, R. J. Glutamine triggers acetylation-dependent degradation of glutamine synthetase via the thalidomide receptor cereblon. Mol. Cell 2016, 61, 809-820.

(19) Del Prete, D.; Rice, R. C.; Rajadhyaksha, A. M.; D’Adamio, L. Amyloid precursor protein (APP) may act as a substrate and a recognition unit for CRL4(CRBN) and Stub1 E3 ligases facilitating ubiquitination of proteins involved in presynaptic functions and neurodegeneration. J. Biol. Chem. 2016, 291, 17209-17227.

(20) Kronke, J.; Udeshi, N. D.; Narla, A.; Grauman, P.; Hurst, S. N.; McConkey, M.; Svinkina, T.; Heckl, D.; Comer, E.; Li, X.; Ciarlo, C.; Hartman, E.; Munshi, N.; Schenone, M.; Schreiber, S. L.; Carr, S. A.; Ebert, B. L. Lenalidomide causes selective degradation of IKZF1 and IKZF3 in multiple myeloma cells. Science 2014, 343, 301-305.

(21) Krönke, J.; Fink, E. C.; Hollenbach, P. W.; MacBeth, K. J.; Hurst, S. N.; Udeshi, N. D.; Chamberlain, P. P.; Mani, D. R.; Man, H. W.; Gandhi, A. K.; Svinkina, T.; Schneider, R. K.; McConkey, M.; Järås, M.; Griffiths, E.; Wetzler, M.; Bullinger, L.; Cathers, B. E.; Carr, S. A.; Chopra, R.; Ebert, B. L. Lenalidomide induces ubiquitination and degradation of CK1alpha in del(5q) MDS. Nature 2015, 523, 183-188.

(22) Matyskiela, M. E.; Lu, G.; Ito, T.; Pagarigan, B.; Lu, C.-C.; Miller, K.; Fang, W.; Wang, N.-Y.; Nguyen, D.; Houston, J.; Carmel, G.; Tran, T.; Riley, M.; Nosaka, L. A.; Lander, G. C.; Gaidarova, S.; Xu, S.; Ruchelman, A. L.; Handa, H.; Carmichael, J.; Daniel, T. O.; Cathers, B. E.; Lopez-Girona, A.; Chamberlain, P. P. A novel cereblon modulator recruits GSPT1 to the CRL4(CRBN) ubiquitin ligase. Nature 2016, $535,252-257$.

(23) Matyskiela, M. E.; Couto, S.; Zheng, X.; Lu, G.; Hui, J.; Stamp, K.; Drew, C.; Ren, Y.; Wang, M.; Carpenter, A.; Lee, C.-W.; Clayton, T.; Fang, W.; Lu, C.-C.; Riley, M.; Abdubek, P.; Blease, K.; Hartke, J.; Kumar, G.; Vessey, R.; Rolfe, M.; Hamann, L. G.; Chamberlain, P. P. SALL4 mediates teratogenicity as a thalidomide-dependent cereblon substrate. Nat. Chem. Biol. 2018, 14, 981-987.

(24) Donovan, K. A.; An, J.; Nowak, R. P.; Yuan, J. C.; Fink, E. C.; Berry, B. C.; Ebert, B. L.; Fischer, E. S., Thalidomide promotes degradation of SALL4, a transcription factor implicated in Duane Radial Ray Syndrome. Elife 2018, 7. DOI: 10.7554/elife.38430

(25) Petzold, G.; Fischer, E. S.; Thomä, N. H. Structural basis of lenalidomide-induced CK1alpha degradation by the CRL4(CRBN) ubiquitin ligase. Nature 2016, 532, 127-130.

(26) Sievers, Q. L.; Petzold, G.; Bunker, R. D.; Renneville, A.; Słabicki, M.; Liddicoat, B. J.; Abdulrahman, W.; Mikkelsen, T.; Ebert, B. L.; Thomä, N. H. Defining the human $\mathrm{C} 2 \mathrm{H} 2$ zinc finger degrome targeted by thalidomide analogs through CRBN. Science 2018, 362, No. eaat0572.

(27) Lai, A. C.; Crews, C. M. Induced protein degradation: an emerging drug discovery paradigm. Nat. Rev. Drug Discovery 2017, 16, 101-114.

(28) Sakamoto, K. M.; Kim, K. B.; Kumagai, A.; Mercurio, F.; Crews, C. M.; Deshaies, R. J. Protacs: Chimeric molecules that target proteins to the Skp1-Cullin-F box complex for ubiquitination and degradation. Proc. Natl. Acad. Sci. U.S.A. 2001, 98, 8554-8559.
(29) Hu, J.; Hu, B.; Wang, M.; Xu, F.; Miao, B.; Yang, C.-Y.; Wang, M.; Liu, Z.; Hayes, D. F.; Chinnaswamy, K.; Delproposto, J.; Stuckey, J.; Wang, S. Discovery of ERD-308 as a Highly Potent Proteolysis Targeting Chimera (PROTAC) Degrader of Estrogen Receptor (ER). J. Med. Chem. 2019, 62, 1420-1442.

(30) Han, X.; Wang, C.; Qin, C.; Xiang, W.; Fernandez-Salas, E.; Yang, C.-Y.; Wang, M.; Zhao, L.; Xu, T.; Chinnaswamy, K.; Delproposto, J.; Stuckey, J.; Wang, S. Discovery of ARD-69 as a highly potent proteolysis targeting chimera (PROTAC) degrader of androgen receptor (AR) for the treatment of prostate cancer. J. Med. Chem. 2019, 62, 941-964.

(31) Winter, G. E.; Buckley, D. L.; Paulk, J.; Roberts, J. M.; Souza, A.; Dhe-Paganon, S.; Bradner, J. E. Phthalimide conjugation as a strategy for in vivo target protein degradation. Science 2015, 348, 1376-1381.

(32) Steinebach, C.; Kehm, H.; Lindner, S.; Vu, L. P.; Köpff, S.; López Mármol, Á.; Weiler, C.; Wagner, K. G.; Reichenzeller, M.; Krönke, J.; Gütschow, M. PROTAC-mediated crosstalk between E3 ligases. Chem. Commun. 2019, 55, 1821-1824.

(33) Lu, M.; Liu, T.; Jiao, Q.; Ji, J.; Tao, M.; Liu, Y.; You, Q.; Jiang, Z. Discovery of a Keap1-dependent peptide PROTAC to knockdown Tau by ubiquitination-proteasome degradation pathway. Eur. J. Med. Chem. 2018, 146, 251-259.

(34) Kargbo, R. B. Treatment of Alzheimer's by PROTAC-Tau protein degradation. ACS Med. Chem. Lett. 2019, 10, 699-700.

(35) Chu, T.-T.; Gao, N.; Li, Q.-Q.; Chen, P.-G.; Yang, X.-F.; Chen, Y.-X.; Zhao, Y.-F.; Li, Y.-M. Specific knockdown of endogenous Tau protein by peptide-directed ubiquitin-proteasome degradation. Cell Chem. Biol. 2016, 23, 453-461.

(36) Boichenko, I.; Bär, K.; Deiss, S.; Heim, C.; Albrecht, R.; Lupas, A. N.; Hernandez Alvarez, B.; Hartmann, M. D. Chemical ligand space of cereblon. ACS Omega 2018, 3, 11163-11171.

(37) Burslem, G. M.; Ottis, P.; Jaime-Figueroa, S.; Morgan, A.; Cromm, P. M.; Toure, M.; Crews, C. M. Efficient synthesis of immunomodulatory drug analogues enables exploration of structuredegradation relationships. ChemMedChem 2018, 13, 1508-1512.

(38) Bartlett, J. B.; Dredge, K.; Dalgleish, A. G. The evolution of thalidomide and its IMiD derivatives as anticancer agents. Nat. Rev. Cancer 2004, 4, 314-322.

(39) Reist, M.; Carrupt, P.-A.; Francotte, E.; Testa, B. Chiral inversion and hydrolysis of thalidomide: mechanisms and catalysis by bases and serum albumin, and chiral stability of teratogenic metabolites. Chem. Res. Toxicol. 1998, 11, 1521-1528.

(40) Chen, T. L.; Vogelsang, G. B.; Petty, B. G.; Brundrett, R. B.; Noe, D. A.; Santos, G. W.; Colvin, O. M. Plasma pharmacokinetics and urinary excretion of thalidomide after oral dosing in healthy male volunteers. Drug Metab Dispos 1989, 17, 402-405.

(41) Schumacher, H.; Smith, R. L.; Williams, R. T. The metabolism of thalidomide: the fate of thalidomide and some of its hydrolysis products in various species. Br. J. Pharmacol. Chemother. 1965, 25, 338-351.

(42) Teo, S. K.; Colburn, W. A.; Tracewell, W. G.; Kook, K. A.; Stirling, D. I.; Jaworsky, M. S.; Scheffler, M. A.; Thomas, S. D.; Laskin, O. L. Clinical pharmacokinetics of thalidomide. Clin. Pharmacokinet. 2004, 43, 311-327.

(43) Beckmann, R. Ueber das Verhalten von Thalidomid im Organismus. Arzneimittelforschung 1963, 13, 185-191.

(44) Chung, F.; Lu, J.; Palmer, B. D.; Kestell, P.; Browett, P.; Baguley, B. C.; Tingle, M.; Ching, L. M. Thalidomide pharmacokinetics and metabolite formation in mice, rabbits, and multiple myeloma patients. Clin. Cancer Res. 2004, 10, 5949-5956.

(45) Nakamura, T.; Noguchi, T.; Miyachi, H.; Hashimoto, Y. Hydrolyzed metabolites of thalidomide: synthesis and TNF-alpha production-inhibitory activity. Chem. Pharm. Bull. 2007, 55, 651-654.

(46) Otogawa, K.; Ogino, Y.; Ishikawa, K.; Tanaka, M.; Shiro, M.; Osaka, T.; Asahi, T. Structural and thermal analyses of a hydrolysis compound of thalidomide. Acta Crystallogr., Sect. A: Found. Adv. 2014, 70, C113.

(47) Krönke, J.; Hurst, S. N.; Ebert, B. L. Lenalidomide induces degradation of IKZF1 and IKZF3. OncoImmunology 2014, 3, No. e941742. 
(48) Schafer, P. H.; Ye, Y.; Wu, L.; Kosek, J.; Ringheim, G.; Yang, Z.; Liu, L.; Thomas, M.; Palmisano, M.; Chopra, R. Cereblon modulator iberdomide induces degradation of the transcription factors Ikaros and Aiolos: immunomodulation in healthy volunteers and relevance to systemic lupus erythematosus. Ann. Rheum. Dis. 2018, 77, 1516-1523.

(49) Matyskiela, M. E.; Zhang, W.; Man, H.-W.; Muller, G.; Khambatta, G.; Baculi, F.; Hickman, M.; LeBrun, L.; Pagarigan, B.; Carmel, G.; Lu, C.-C.; Lu, G.; Riley, M.; Satoh, Y.; Schafer, P.; Daniel, T. O.; Carmichael, J.; Cathers, B. E.; Chamberlain, P. P. A Cereblon Modulator (CC-220) with Improved Degradation of Ikaros and Aiolos. J. Med. Chem. 2018, 61, 535-542.

(50) Capitosti, S. M.; Hansen, T. P.; Brown, M. L. Facile synthesis of an azido-labeled thalidomide analogue. Org. Lett. 2003, 5, 2865-2867.

(51) Joossens, J.; Van der Veken, P.; Lambeir, A.-M.; Augustyns, K.; Haemers, A. Development of irreversible diphenyl phosphonate inhibitors for urokinase plasminogen activator. J. Med. Chem. 2004, 47, 2411-2413.

(52) Kanuma, K.; Omodera, K.; Nishiguchi, M.; Funakoshi, T.; Chaki, S.; Nagase, Y.; Iida, I.; Yamaguchi, J.-i.; Semple, G.; Tran, T.-A.; Sekiguchi, Y. Identification of 4-amino-2-cyclohexylaminoquinazolines as metabolically stable melanin-concentrating hormone receptor 1 antagonists. Bioorg. Med. Chem. 2006, 14, 3307-3319.

(53) Nouch, R.; Cini, M.; Magre, M.; Abid, M.; Diéguez, M.; Pàmies, O.; Woodward, S.; Lewis, W. Enantioselective synthesis of 6,6disubstituted pentafulvenes containing a chiral pendant hydroxy group. Chem.-Eur. J. 2017, 23, 17195-17198.

(54) Cao, R.; Müller, P.; Lippard, S. J. Tripodal tris-tacn and tris-dpa platforms for assembling phosphate-templated trimetallic centers. J. Am. Chem. Soc. 2010, 132, 17366-17369.

(55) Steinebach, C.; Lindner, S.; Udeshi, N. D.; Mani, D. C.; Kehm, H.; Köpff, S.; Carr, S. A.; Gütschow, M.; Krönke, J. Homo-PROTACs for the chemical knockdown of cereblon. ACS Chem. Biol. 2018, 13, 2771-2782.

(56) Boichenko, I.; Deiss, S.; Bär, K.; Hartmann, M. D.; Hernandez Alvarez, B. A FRET-based assay for the identification and characterization of cereblon ligands. J. Med. Chem. 2016, 59, 770-774.

(57) Kabsch, W. Xds. Acta Crystallogr., Sect. D: Biol. Crystallogr. 2010, 66, 125-132.

(58) Vagin, A.; Teplyakov, A. Molecular replacement with MOLREP. Acta Crystallogr., Sect. D: Biol. Crystallogr. 2010, 66, 22-25.

(59) Emsley, P.; Lohkamp, B.; Scott, W. G.; Cowtan, K. Features and development of Coot. Acta Crystallogr., Sect. D: Biol. Crystallogr. 2010, $66,486-501$.

(60) Schrodinger, LLC. The PyMOL Molecular Graphics System, Version 2.2.1. 